\title{
A ética do silêncio racial no contexto urbano: políticas públicas e desigualdade social no Recife, 1900-1940
}

The ethics of racial silence in urban Brazil: Public policies and social inequality in Recife, 1900-1940

hitps://doi.org/10.1590/1982-02672020v28d le15

\section{BRODWYN MICHELLE FISCHER'}

hitps://orcid.org/0000-0002-0468-8557

University of Chicago / Chicago, Estados Unidos

RESUMO: Mais de meio século após o preconceito racial ter se tornado o principal alvo dos movimentos urbanos pelos direitos civis nos Estados Unidos e na África do Sul, e décadas depois do surgimento dos movimentos negros contemporâneos no Brasil, o conjunto de ferramentas legislativas criado no Brasil para promover o direito à cidade ainda adere à longa tradição brasileira de silêncio acerca da questão racial. Este artigo propõe iniciar uma exploração das raízes históricas desse fenômeno, remontando ao surgimento do silêncio sobre a questão racial na política urbana do Recife, Brasil, durante a primeira metade do século XX. O Recife foi e é um exemplo paradigmático do processo pelo qual uma cidade amplamente marcada por traços negros e africanos chegou a ser definida política e legalmente como um espaço pobre, subdesenvolvido e racialmente neutro, onde as desigualdades sociais originaram na exclusão capitalista, e não na escravidão e nas ideologias do racismo científico. Neste sentido, Recife lança luzes sobre a política urbana que se gerou sob a sombra do silêncio racial.

PALAVRAS-CHAVE: Recife. Direito à cidade. Negro. Desigualdade. Mocambo. Informalidade.

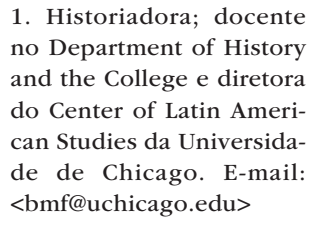

no Department of History and the College e diretora de de Chicago. E-mail <bmf@uchicago.edu> 
ABSTRACT: More than half a century after racial prejudice became central to urban civil rights movements in the United States and South Africa, and decades after the emergence of Brazil's contemporary Black movements, Brazil's internationally recognized body of rights-to-the-city legislation still adheres to the country's long historical tradition of racial silence. This article explores the historical roots of this phenomenon by focusing on the emergence of racial silence in Recife, Brazil during the first half of the 20th Century. Recife was and remains a paradigmatic example of the process through which a city marked by its Black and African roots came to be legally and politically defined as a poor, underdeveloped and racially neutral space, where social inequalities derived from capitalist exclusion rather than from slavery and scientific racism. As such, Recife's experience sheds light on the urban policies that were generated in the shadow of racial silence.

KEYWORDS: Recife. Right to the City. Black. Inequality. Mocambo. Informality. 
INTRODUÇÃO

Até que ponto as cidades informais do Brasil - suas favelas, periferias, mocambos e palafitas - são espaços negros?

À primeira vista, a pergunta pode parecer tola. Todos os indicadores estatísticos da década de 1940 até o presente mostram que a população de afrodescendentes nesses espaços é desproporcionalmente grande. ${ }^{2}$ A ninguém poderia passar despercebido o brilho da pele morena na iconografia das favelas. No cinema e na realidade, as favelas e periferias brasileiras pulsam com os ritmos do samba, do jongo, do maracatu, do afro-reggae e do funk. Os mapas da segregação social demarcam claramente a sobreposição entre a ascendência afro e as muitas periferias urbanas do Brasil. ${ }^{3}$ Favelas e mocambos geralmente têm suas origens nos quilombos, nas emancipações, na abolição, e em processos de gentrificação que expulsaram afrodescendentes desproporcionalmente dos centros urbanos. Uma geração pioneira de ativistas afro-brasileiros emergiu dos movimentos sociais urbanos do país. ${ }^{4}$ Os corpos vitimados pela violência nas favelas são majoritariamente negros. As estatísticas só reforçam o que é óbvio para quem presta a menor atenção: os afrodescendentes ocupam desproporcionalmente os espaços urbanos pobres e informais do Brasil. Até mesmo os moradores brancos das favelas, que são uma minoria significativa, acabam transformados em "quase pretos de tão pobres". ${ }^{5}$ Como pode uma realidade tão autoevidente quanto a negritude das favelas sequer ser posta em dúvida?

No entanto, quando passamos do domínio dos sentidos para o das abstrações do planejamento urbano e da política, a questão racial assume um significado diferente. Nas últimas décadas, o Brasil emergiu como líder global na cruzada pelo "direito à cidade". "Com raízes nos movimentos sociais de massa de meados do século XX, bem como em concepções políticas da esquerda pósditadura, o Brasil criou o mais ambicioso aparato legislativo do mundo para lidar com problemas urbanos, reconhecido como modelo global pela ONU Habitat em 2006. A Constituição de 1988 estabeleceu políticas urbanas que priorizam a função social da cidade e da propriedade urbana. $\bigcirc$ Estatuto da Cidade, de 2001 , elaborou uma vasta gama de instrumentos legais destinados a garantir esses princípios, institucionalizar a governança participativa e garantir terra, moradia, saneamento, infraestrutura, serviços públicos, transporte e equipamentos de lazer aos moradores urbanos. $\bigcirc$ Estatuto também determinou que todas as cidades com mais de 20 mil habitantes tivessem planos diretores decenais. Em 2016, quase a metade das cidades brasileiras haviam cumprido essa determinação. Embora a legislação urbana do Brasil tenha sido justamente criticada como irrealista, subutilizada, contraditória e mal aplicada, o fato permanece: o compromisso legal
2. Estatísticas exatas são dificultadas pelas múltiplas definições de "cidade informal", mas a maioria das estimativas - surpreendentemente estáveis ao longo do tempo - indicam que algo em torno de $70 \%$ dos moradores de favelas cariocas se declaram pretos ou pardos. A associação entre informalidade e negritude remonta às origens da informalidade urbana, mesmo em São Paulo. Cf. Fischer (2008); Rolnik (1997).

3.Cf. Rios Neto; Riani (2007), Gusmão (2015).

4. Cf. Alberti; Pereira (2007)

5. Letra de Caetano Veloso, "Haiti".

6. Cf. Fernandes (2007); Fernandes (2013); e Rolnik (2011). 
7. Perry (2013); Paschell (2018); Collins (2015); Memórias do esquecimento (2011); Cicalo (2015); Poets (2017).

8. Sobre silêncio racial, cf. Mattos (1993), Albuquerque (2009), e Fischer; Grinberg; Mattos (2018). Para um relato novo e provocativo sobre o papel de leis e políticas nas dinâmicas raciais nos Estados Unidos, cf. Rothstein (2017) do Brasil por cidades justas, participativas e igualitárias se estende por centenas de milhares de páginas. Nesses documentos todos, as favelas, as periferias e os assentamentos urbanos informais assumem um papel central como expressões, na geografia e na lei, da desigualdade urbana e do sofrimento humano.

O que surpreende, porém, é que esses espaços informais que ocupam lugar tão destacado raramente apareçam como espaços negros na interpretação dos técnicos e ativistas que moldam a infraestrutura legal das cidades brasileiras. Em todos aqueles calhamaços de estatutos urbanos, há um escasso reconhecimento dos papéis que o preconceito racial desempenha (histórica e atualmente) no fomento da injustiça urbana e social. A Constituição de 1988 garante explicitamente a igualdade racial, mas o Estatuto da Cidade não menciona especificamente nem a marginalização espacial racializada nem os legados urbanos do viés racista. Salvador e Fortaleza são as únicas grandes cidades que chegaram a incluir a luta contra a discriminação racial entre os princípios norteadores de seus planos diretores. Pagando tributo às raízes do direito à cidade no igualitarismo liberal e a sua ligação mais recente com a crise da esquerda no final do século XX, a legislação urbana brasileira se concentra predominantemente em garantir a igualdade radical a cidadãos cujas únicas diferenças relevantes são materiais e relativas. Não há dúvida de que, no Brasil, a questão racial é central para a "questão urbana" contemporânea: comunidades se mobilizam contra a violência policial racializada, quilombos são um caminho juridicamente viável para formalizar direitos de propriedade urbana, afrodescendentes e seus aliados se organizam pela preservação da memória negra na paisagem urbana e discursos políiticos que emanam de favelas e periferias têm grande poder de mobilização da consciência negra. ${ }^{7}$ Não obstante, mais de meio século após o preconceito racial ter se tornado um ponto fundamental dos movimentos urbanos pelos direitos civis nos Estados Unidos e na África do Sul, o conjunto inovador de ferramentas legislativas criado no Brasil adere à longa tradição brasileira de silêncio acerca da questão racial. ${ }^{8}$

No terreno da política urbana, esse silêncio tem profundo impacto: ajuda a obscurecer a influência explícita do racismo e de processos históricos racializados no desenvolvimento urbano e desestimula a criação de ferramentas específicas para combater tais desigualdades. No entanto, a ausência da questão racial na legislação é sintomática de um imbróglio histórico maior. Ao contrário do que acontece nos Estados Unidos ou na África do Sul, as leis brasileiras têm mantido um silêncio esmagador sobre a questão racial desde a Independência. Até meados do século XX, a maioria dos brasileiros e dos observadores estrangeiros - incluindo muitos afro-americanos - entendia tal silêncio como um ideal, e não uma omissão. Era, nesse sentido, um elemento essencial na construção ideológica da justamente 
deslegitimada "democracia racial" brasileira. Nas últimas décadas, ativistas e acadêmicos (brasileiros e estrangeiros) passaram a contestar vigorosamente essa visão, questionando a lógica e os significados do silenciamento da questão racial. Entre muitas outras coisas, essa atuação revelou o papel crítico le muitas vezes intencional) desse silenciamento no enfraquecimento da consciência coletiva da discriminação, bem como as formas sinuosas pelas quais a aparente neutralidade racial da lei permitiu e até perpetuou disparidades sistemáticas com viés racista. ${ }^{9}$ Essas críticas deixaram em seu rastro uma agenda de pesquisa inquietante, na qual a história tem um papel decisivo. Como entender os processos pelos quais as desigualdades raciais se perpetuaram no Brasil quando os registros oficiais muitas vezes silenciaram a questão da raça e quando a disparidade racializada nos padrões de vida raramente se deveu a um racismo institucional explicitamente articulado? Como relacionar um fato empírico amplamente reconhecido - o acesso reduzido dos afrodescendentes à mobilidade social - a processos sociais ou institucionais enraizados e sistemáticos? Como explicar o surgimento e a persistência do silêncio acerca da raça não apenas como discurso hegemônico da elite, mas também como esperança e estratégia dos próprios afrodescendentes?

As cidades brasileiras parecem ser o espaço óbvio onde investigar essas questões, tanto porque têm sido elas o laboratório para as análises mais detalhadas e críticas sobre o racismo brasileiro quanto pelo fato de que as leis e as instituições do Estado encontram mais densidade e força nos contextos urbanos. Porém, em pleno século XXI, as dinâmicas legais e institucionais em relação às desigualdades raciais urbanas no Brasil permanecem ofuscadas, especialmente no que diz respeito a formas de discriminação que diferem daquelas já investigadas nos Estados Unidos, na África do Sul ou na Europa. ${ }^{10}$ Conforme se comprova pela legislação urbana do Brasil, o problema da pobreza urbana no país - assim como na maior parte do chamado Sul Global - sobrepõe-se substancialmente lembora não completamente) ao problema da informalidade urbana. No entanto, a história urbana da informalidade é pouco estudada e sua dimensão racial permanece ainda mais obscura. ${ }^{11}$ Por que o surgimento de favelas e mocambos como um "problema urbano" coincidiu com a Abolição? Por que pessoas afrodescendentes, em contingente desproporcional, têm vivido e permanecido em favelas, mocambos, periferias e outros espaços informais e marginalizados pelo Estado? De que forma a problematização da informalidade tem justificado investimento público desigual, que acaba por ampliar o abismo sociorracial? De que outras maneiras a dinâmica da informalidade urbana contribui para criar desigualdades duradouras com viés racista? $\mathrm{E}$, considerando tudo isso, por que tantos movimentos sociais urbanos do século XX articularam suas reivindicações em termos racialmente neutros?
9. Para um apanhado geral, cf. Fischer; Grinberg; Mattos (2018).

10. O estudo histórico de raça e urbanidade no século XX no Brasil atraiu atenção significativa nas décadas de 1930, 1940 e 1950 (Freyre, Pierson, Cardoso e Ianni, Fernandes, Costa Pinto), mas em seguida foi eclipsado pelo foco na teoria da migração, da pobreza e da marginalidade. Com exceções significativas (Andrews, Telles, Rolnik), estudiosos brasileiros e brasilianistas só recentemente voltaram a se concentrar nos mecanismos históricos e legados do racismo na paisagem urbana brasileira do século 20, cf. Perry (2013); Oliveira; Oliveira (2015), Oliveira (2008), Santos (2012), Garcia (2009), Collins (2015); Alberto (2011), Fischer (2004 e 2007).

11. Para historiografia recente sobre informalidade, cf. Fischer (2014; 2008), Gonçalves (2013), Holston (2008), McCann (2014), Brum (2013) e Gominho (1998). Sobre mecanismos específicos ligando investimento público e valorização da terra a padrões racializados de informalidade, cf. Rolnik (1997) e Fischer (2007). Para laços conceituais entre raça e "a cidade", cf. Lira (1999b). 
12. O termo "mucambópolis" foi cunhado pelo geógrafo Mario Lacerda de Melo em Pernambuco, p. 151.

13. Gominho (1998), Cézar (1995), Bezerra (1965) e Assies (1991).

14. Cf. Assies (1994), Souza (2001), Fernandes (2001), Miranda; Moraes (2007), Moraes (2017).

15. Termo de Chalhoub (1990).
Este artigo propõe iniciar uma exploração dessas questões remontando ao surgimento do silêncio sobre a questão racial na políitica urbana do Recife, Brasil, durante a primeira metade do século XX. $\bigcirc$ Recife não é uma potência econômica como São Paulo, nem um berço universalmente reconhecido da identidade cultural afrodescendente como Salvador. Seus mocambos não ficam dependuradas em morros fotogênicos, e a violência na cidade, embora intensa e racializada, em geral não tem caráter espetacular. No entanto, o Recife é um espaço particularmente elucidativo para se pensar a história da política racial e sua relação com a informalidade brasileira. A cidade informal sempre compôs parte especialmente importante de seu tecido urbano: enquanto São Paulo era a metrópole do país, o Recife era sua mucambópolis. ${ }^{12}$ Lá, a cidade informal emergiu no contexto da Abolição, e em vários sentidos serviu para perpetuar os sistemas de poder patriarcal que haviam sustentado a escravidão. $\bigcirc$ Recife era também a cidade de Gilberto Freyre, e apegou-se com especial afinco aos ideais de mestiçagem e silêncio racial.

Ao mesmo tempo, Recife foi a incubadora de uma longa série de pensadores sociais significativos e inovadores, começando com Joaquim Nabuco e se estendendo até Paulo Freire. Em meados do século XX, também foi berço de comunistas militantes e ativistas-chaves no movimento de teologia da libertação. Ambos grupos foram fundamentais para fazer do Recife um laboratório para alguns dos movimentos populares urbanos mais importantes do Brasil. ${ }^{13} \mathrm{Na}$ década de 1970, junto com Belo Horizonte, a capital pernambucana foi pioneira em traduzir essa mobilização urbana em reformas legislativas que mais tarde seriam integradas ao corpo de legislação que visava garantir o direito à cidade. ${ }^{14} \bigcirc$ Recife foi e é, em suma, um exemplo paradigmático do processo pelo qual uma cidade informal amplamente marcada por traços negros e africanos passou a ser problematizada e caracterizada como espaço racialmente neutro, definido política e legalmente em termos de seus problemas de "subdesenvolvimento" ou "exclusão social." Como tal, serve muito bem para lançar luzes sobre a política urbana que se gerou sob a sombra do silêncio racial.

\section{A CIDADE NEGRA DO RECIFE ${ }^{15}$}

Em meados da década de 1930, um médico brasileiro chamado Josué de Castro se lançou à tarefa de retratar sua cidade natal. Achou difícil. "Recife, capital do Nordeste" não era "cidade duma só cor, nem dum só cheiro, como muitas 
encontradas por Kipling [...]". ${ }^{16}$ Era, isso sim, um "mosaico de côres, de cheiros e de sons", um "desadorado caos urbano, reflexo confuso da fusão violenta de várias expressões culturais". ${ }^{17}$ No centro, avenidas em estilo europeu partiam de uma praça monumental ladeada por imponentes edifícios e "magníficos estabelecimentos comerciais". Mas tamanha sofisticação desembocava abruptamente num aglomerado desordenado. Ruínas decaídas da cidade colonial dividiam espaço com cinemas baratos, lojas de atacado e casas de famílias aspirantes à burguesia. Os bairros ocupados por famílias tradicionais jaziam em imponente decadência, ao passo que as vizinhanças de novos ricos eram chocantes em sua ostentação e "mau gosto". ${ }^{18}$ A única coisa a amenizar os contrastes do Recife era a paisagem natural; a cidade, embebida em água, margeada pelo mar e atravessada por riachos e rios, estava sempre iluminada "pelos reflexos intensos da luz sôbre as águas". ${ }^{19}$

Emergindo das planícies lamacentas das marés produzidas por aquelas mesmas águas surgiam células de uma outra cidade: os mocambos, barracos rústicos que abrigavam quase metade da população do Recife. ${ }^{20}$ Castro começara a trabalhar nos mocambos ainda um jovem médico, cuidando dos doentes e realizando pioneiras pesquisas nutricionais. Aqueles assentamentos continuariam a assombrá-lo ao longo de sua célebre carreira como escritor, geógrafo, político, diplomata, dissidente político e militante revolucionário na luta contra a fome. A partir de suas primeiras experiências, Castro descreveu assim os mocambos:

\footnotetext{
"Afogados", "Pina", "Santo Amaro", zonas dos mangues, dos "mocambos", dos operários, dos sem-profissão, dos inadaptados, dos que desceram do sertão na fome e não puderam vencer na cidade, dos rebelados e dos conformados - dos vencidos. Zona dos "mocambos". Cidade aquática, com casas de barro batido a sopapo, telhados de capim, de palha e de fôlhas de flandres. Cumbucas negras boiando nas águas. Mocambos - verdadeira senzala remanescente fracionada em torno às Casas Grandes da Veneza Americana. Poesia primitiva de negros e mestiços fazendo xangô e cantando samba. Fisionomia africana. ${ }^{21}$
}

recurso manifesto de Castro à terminologia racial teve vida breve: já um intelectual maduro, ele não relacionaria mais a miséria dos mocambos à predominância negra. Seus escritos datam, na verdade, do momento em que a política acerca daquelas ocupações resvalava para o silenciamento da questão racial, ainda que alusões à raça tenham persistido de forma mais sutil. Para a geração de intelectuais e ativistas da qual Castro fazia parte, os mocambos se tornaram um poderoso símbolo da privação material e das brutalidades mais arcaicas do subdesenvolvimento: eram o sertão encravado no núcleo urbano, a senzala teimosamente persistente numa sociedade livre, a ameaça e a promessa de revolução social no coração da ordem política.
16. Castro (1957, p. 13).

17. Ibid., p. 16.

18. Ibid., p. 15

19. Ibid., p. 16

20. Em 1923, o número de mocambos superava levemente o de moradias formais. Pernambuco (1924, p. 3).

21. Ibid., p. 15-16. Esta descrição é muito semelhante a uma de autoria de Gilberto Freyre publicada alguns anos antes. Freyre; Jardim (1961, p. 161). 
22. Freyre (1937, p. 20); Lira (1999a, p. 298-9).

23. Tollenare (1905, p. 41-2).

24. Freyre (2004, p. 350 , 413).

25. De um total de 37.735 prédios recenseados no Recife em 1913, 66\% (24.817) eram casas de taipa ou mocambos. Recife (1915, p. 83). A população total da cidade girava em volta de 217.076.

26. Cf. Fischer (2014). Rosa Lima argumenta que, pelo fato de muitos mucambeiros serem ex-escravos, o mocambo foi "naturalizado" durante esses anos; para gente de fora, prossegue ela, parecia que o lugar daquelas pessoas era mesmo a lama. Lima (2005, p. 106-7).
Mas, no mundo habitado por Castro na juventude, não restava dúvida de que os mocambos eram lugares profundamente africanos. A ligação de uma coisa a outra já começava pelo nome: mucambo era uma palavra da língua quimbundo que se referia a comunidades quilombolas, antes de passar a significar barraco rústico ou de favela. ${ }^{22} \mathrm{Na}$ estrutura física, os mocambos eram simplesmente essas cabanas feitas de barro, madeira descartada, palha e cobertura de sapê, mais tarde substituído por lata. Mas no século XIX essas estruturas já estavam inextricavelmente ligadas à história da escravidão e da emancipação no Brasil. Já em 1816, L.F. Tollenare, um comerciante francês, reparou em "cabanas feitas de folhagem" nos mangues do distrito de Afogados. Seus habitantes eram "mulatos e negros livres", os quais podiam - graças à abundância de caranguejos - "se entregar à ociosidade descuidada que constitui toda a sua felicidade". ${ }^{23}$

Segundo Gilberto Freyre, os mocambos urbanos começaram a proliferar porque: "Para muito negro ou pardo, sôfrego de liberdade, era o mucambo melhor que a senzala de pedra e cal, pegada à casa do senhor [...]". Essa associação inicial entre mocambos e negros libertos se aprofundou no século XIX, à medida que as cidades cresciam e a liberdade eclipsava a escravidão: "As mucambarias ou aldéias de mucambos, palhoças ou casebres [...] representaram, evidentemente, da parte de negros livres ou fugidos [...] o desejo de reviverem estilos africanos de habitação e convivência $[\ldots]^{\prime \prime} .{ }^{24}$ Se Freyre estava ou não certo sobre as razões pelas quais os afrodescendentes viviam em mocambos, suas análises refletiam um certo senso comum. Barracos existiam desde tempos imemoriais, mas os mocambos se tornaram uma formação à parte: aglomerados nos interstícios de dinâmicos centros urbanos, envoltos em vaga nostalgia pela África e num intenso desejo de liberdade, eram filhos da urbanização e da emancipação, um fenômeno desconcertantemente moderno.

Alusões desse tipo persistiram, mesmo com os mocambos sendo cada vez mais habitados por brancos pobres ou mestiços que pouco tinham a ver com a escravidão, a maioria refugiados da mortandade das secas no sertão. Em 1913, o número de mocambos no Recife superava o de casas formais, estendendo sua presença por todo lado, da parte elevada dos mangues aos quintais senhoriais e às encostas desocupadas na periferia a noroeste da cidade. ${ }^{25}$ Até o início do século XX, gente de fora raramente fazia referência aos mocambos. Como em outros lugares da América Latina, barracos rústicos eram, como a própria pobreza, algo que se esperava ver como parte da paisagem urbana. ${ }^{26}$ A partir de 1900, no entanto, os mocambos começaram a emergir como um problema social singular, alvo de uma ampla gama de procupações. Médicos e planejadores urbanos se inquietavam com a constituição precária das moradias, com a umidade, as 
inundações, a superlotação, e pelo potencial foco de doenças epidêmicas que representavam. ${ }^{27}$ Outros observadores refletiam sobre o que os mocambos poderiam revelar do caráter dos recifenses, ou da capacidade de modernização da cidade. Os autores do censo de 1913 expressaram inquietação não só pelo "perigo que, sob o ponto de vista da salubridade, [o mocambo] representa", mas também pelo fato de que "dá uma impressão desagradável a grande parte da cidade". ${ }^{28} \bigcirc$ poeta paulista Rui Ribeiro Couto, que fez escala no Recife em 1928 a caminho de seu primeiro posto diplomático, em Marselha, escreveu que a população do Recife sentia "vergonha de que os turistas tirem fotografias das cabanas de palha" ${ }^{29}$

$\bigcirc$ substrato racista dessa vergonha às vezes surgiu mais nitidamente. $\bigcirc$ diretor de Saúde e Assistência Social Amaury de Medeiros afirmou que os mocambos se pareciam com "os aldeamentos negros do Senegal" e que seu "atraso" causava um "um infalível ar de nojo e pena" nos "civilizados". Evocando as disquisições do século XIX sobre a degeneração das culturas "primitivas" quando postas em contato com a "civilização", Medeiros argumentava que ele preferia as cabanas primitivas dos "negros" em Dacar aos mocambos do Recife, porque aquelas tinham certa pureza selvagem e não eram construídas das sobras da sociedade moderna, dando uma impressão de miséria e indigência. ${ }^{30}$

Condenações retóricas dos mocambos tinham consequências significantes. As autoridades reiteradamente proibiam a construção e a reforma de mocambos nos distritos centrais da cidade. Ainda que as normas fossem articuladas numa linguagem técnica e desracializada, era impossível separar o regulamento dos mocambos do seu subtexto racial. ${ }^{31} \mathrm{Na}$ década de 1920, conclamações por incêndios criminosos de mocambos coexistiram com campanhas mais ponderadas por sua erradicação. ${ }^{32}$ Tais regulamentos e campanhas, porém, tiveram pouco impacto prático. A população do Recife se expandiu rapidamente no início do século XX, crescimento impulsionado em grande medida pela migração campo-cidade. $\bigcirc$ custo da moradia era alto, e os políticos da cidade não podiam levar a cabo uma erradicação draconiana das únicas habitações que os pobres podiam pagar. Alguns moradores dos mocambos exerciam o direito a voto, e alguns especuladores e senhorios eram também chefes políticos locais que se beneficiavam do apoio dos mocambeiros. Por mais constrangedores que parecessem os assentamentos às sensibilidades dos recifenses mais ricos e por mais perigosos que fossem do ponto de vista da saúde pública, os mocambos ainda constituíam aproximadamente metade das moradias da capital pernambucana no início da década de 1930. ${ }^{33}$
27. Orlando (1908, p. 139).

28. Recife (1915, p. 82-83).

29. Couto, "Cartas de França”, A Provincia, 8 maio 1929, citado em Lira (1999a, p. 311). Couto também é citado em Freyre (2004, p. 782) para outras representações líricas do mocambo.

30. Medeiros (1926) apud Lira (1999a, p. 310). Para mais sobre Medeiros: Melo (1985, p. 49-52).

31. Essas normas evoluíram gradualmente, começando com regulamentações dispersas do século XIX relativas à construção e ao saneamento (a Lei Municipal $\mathrm{n}^{\circ} 4$ de 1893, por exemplo, foi um marco importante). A regulamentação começou a tomar forma mais abrangente com o surgimento de preocupações sanitárias da belle-époque, o que resultou em amplas reformas dos sistemas de esgoto e drenagem do Recife. A Lei Municipal 1051, de 1919, foi um ponto de virada porque não apenas codificou normas urbanísticas, mas também estabeleceu o primeiro sistema de zoneamento do Recife, um componente crucial do qual foi o banimento dos mocambos e casas de taipa das zonas "primárias" e "urbanas" do Recife (mocambos ainda eram permitidas nas zonas suburbanas e rurais do município). Depois de 1919, a cidade continuou a restringir gradualmente a construção e reparação dos mocambos; ao mesmo tempo, tanto a cidade quanto o estado impuseram impostos cada vez mais onerosos aos mocambos. Esse processo foi consolidado com o regulamento de construções de 1936 (Decreto 374 ), que refinou o sistema de zoneamento e reforçou as proibições aos mocambos e seus proprietários. No final da década de 1930, uma série de decretos intensificaram a proibição do mocambo nas áreas centrais 
do Recife, como parte da campanha antimocambo de Agamenon Magalhães. Embora a maioria dessas leis não fosse aplicada, elas efetivamente excluíam os mocambos do tecido legal do Recife. Para mais detalhes, cf. Melo (1985), Gominho (1998); Lira (1999a; 1994), Medina (2018, p. 52-56).

32. Lira (1999a, p. 311).

33. Em 1923, a população do Recife era de 313.000 , e a cidade tinha 19.079 "residências" e 19.947 "mocambos", cf. Pernambuco (1924). Em 1931-2, o Recife talvez abrigasse 446.178 almas e tivesse 23.210 mocambos e 23.869 prédios, Gominho (1998, p. 29-30). Em 1935, o Serviço Nacional de Febre Amarela estimava o numero de mocambos em 44.750, Lira (1994, p. 747).

34. Cf. Coelho (1999), Maio; Santos (1996). Sobre planejamento urbano, cf. Benchimol (1990).

35. Cf. Schwarcz (1993).

36. Cf. Chalhoub (1996).

37. Cf. Hochman (1998), Lima; Hochman (1996) e Borges (1993).

38. Cf. Blake (2003).

\section{OS MOCAMBOS NA VISÃO DOS PROFISSIONAIS}

Surgimento dos mocambos como um "problema social" no olhar da cidade letrada, por mais que tivesse raízes racializadas, também marcou os primórdios de concepções inovadoras sobre suas causas e significados. Algumas das primeiras reavaliações vieram de profissionais técnicos que haviam começado desde o final do século XIX a enquadrar questões sociais como assunto de "ciência", a serem resolvidas com planejamento técnico racional. ${ }^{34}$ Os engenheiros, médicos, juristas e planejadores urbanos brasileiros não fugiam do padrão de preconceito racial e social que então caracterizou suas profissões, e as políticas que implementavam muitas vezes serviam para aprofundar as desigualdades do país. ${ }^{35}$ Engenheiros e planejadores urbanos atuavam em cooperação com especuladores imobiliários e promoveram reformas radicais sem levar em consideração as comunidades e os costumes dos moradores pobres; médicos sanitaristas invocaram a ciência médica em nome do combate a doenças que matavam desproporcionalmente os brancos, ignorando a tuberculose e outros flagelos endêmicos que acometiam os brasileiros pobres e afrodescendentes. ${ }^{36}$

No entanto, as classes profissionais eram heterogêneas, e muitos abraçaram discursos tecnocráticos ou liberais nos quais a questão da raça tinha um papel secundário. Ao dar visibilidade aos fatores técnicos e estruturais por trás dos problemas mais sérios do país, ao tratá-los como problemas sociais, em vez de falhas biológicas ou comportamentais, e ao sugerir que a pobreza e o analfabetismo exigiam soluções coletivas, alguns profissionais abriram caminho para políticas sociais inimagináveis uma geração antes. Nas décadas de 1910 e 1920, a primeira vanguarda desse movimento inaugurou o campo da saúde pública rural. Os médicos e autoridades sanitárias não abríam mão da idéia de que os brasileiros rurais eram enfraquecidos pela biologia ou pelas herências da escravidão. Mas argumentavam também que os camponeses eram debilitados pela desnutrição e pelas doenças endêmicas, condições que pesavam consideravelmente no atraso do país. ${ }^{37} \mathrm{~A}$ associação entre meio rural e pobreza gerou preconceitos novos, muitos dos quais causaram tanto dano aos afro-brasileiros quanto o preconceito racial explícito que, em parte, vieram substituir. ${ }^{38}$ Ainda assim, estabeleceu-se o fato de que doença, desnutrição e analfabetismo eram problemas para os quais havia soluções concretas e imediatas, o que já era muito diferente das noções de determinismo racial e branqueamento cujo ideal era a destruição transgeracional de povos e culturas.

Artur Orlando - um renomado jurista da faculdade do Recife, também ensaísta, político e editor de jornal - foi um dos primeiros a ver os mocambos pelas lentes da saúde pública e do planejamento urbano. Porto e Cidade do Recife 
(1908), de sua autoria, é um livro tipicamente híbrido, a um só tempo um tributo lírico à cidade, uma investigação sobre saúde e clima e um plano de soluções técnicas e políticas para os problemas econômicos, educacionais, de saúde e bem-estar da capital pernambucana. Esse hibridismo não poderia ser mais explícito do que no tratamento dado por Orlando à questão habitacional: "A habitação não diz respeito somente à existência domestica, importa principalmente à higiene nacional." 39 "Higiene", aqui, incluía tudo, desde hábitos pessoais até educação, condições de moradia e normas regendo os locais de trabalho. E "reforma da cidade" não era

um simples problema de hidráulica, de arquitetura ou de estética, mas de economia social em sua mais larga acepção, prendendo-se intimamente à vida e desenvolvimento da população e da cidade... a habitação insalubre é o maior fator de miséria social. ${ }^{40}$

Orlando sentia repugnância pelos mocambos e pelo "pleno desprezo pelo asseio" de seus habitantes. ${ }^{41}$ Porém, desprezava também explicações de doença que eram abertamente raciais e climáticas - via tais explicações como manifestações do imperialismo estrangeiro - e recusava firmemente qualquer associação direta entre os mocambos e a África, a escravidão ou a mistura racial. ${ }^{42}$

Nas duas décadas seguintes, reformas urbanas e medidas sanitárias se sucederam rapidamente, provocando atribulações em inúmeras comunidades, ainda que ajudassem a reduzir a incidência de doenças epidêmicas, além de promover a ampliação do porto e a urbanização de áreas periféricas da cidade. Os mocambos foram alvos frequentes dessas reformas e "eterna preocupação dos nossos hygienistas". ${ }^{43}$ Os técnicos continuavam convencidos de que alijavam tanto moral quanto fisicamente seus residentes; o engenheiro Umberto Gondim os chamou de "veículos de miséria e morte". 44 Sanitaristas como Paulo Guedes viam médicos e engenheiros como "apóstolos" capazes de salvar cidades pelo saneamento básico, e consideravam os inadequados lares proletários do Recife como a célula a partir da qual brotavam os males da sociedade. As condições precárias do mocambo precisavam ser eliminadas, não apenas para prevenir doenças fatais, mas também para promover o melhoramento da "raça". ${ }^{45}$

Mas Guedes entendia raça no sentido de nacionalidade, e o que defendia era uma eugenia neolamarquiana, orientada para a higiene, a sociologia e a psicologia, e não para uma "limpeza" genética. ${ }^{46}$ Ele e seus contemporâneos faziam relativamente pouco uso da linguagem racial, concentrando-se em políticas técnicas e concretas: expansão do sistema de drenagem, acesso a esgoto e abastecimento de água; moradia a preços acessíveis; erradicação rigorosa de mosquitos; e melhoria da "educação" higiênica, com ênfase na limpeza doméstica, a dieta e o aprimoramento
39. Orlando (1908, p. 46).

40. Ibid., p. 51.

41. Ibid., p. 56.

42. Ibid., p. 122-3.

43. Guedes (1928, p. 62).

44. Gondim, "Habitação".

45. Guedes (1928, p. 62, 72).

46. Essa era a típica postura de brasileiros eugenistas; cf. Stepan (1991). 
47. Citado em Lopes, Jornal do Comércio, 19 de outubro de 1923. O comentário se refere à assertiva de Miguel Pereira, em 1916, de que o Brasil era "um imenso hospital", cf. Hochman (1998). Blake (2003, p. 224) argumenta ainda que a as discussões sanitaristas em relação ao mocambo geralmente não enfatizavam a questão racial. 48. Castro (1957, p. 75-6). nas técnicas de autoconstrução doméstica. Até mesmo o carioca Amaury de Medeiros, o autoritário diretor de Saúde Pública para quem os mocambos evocavam o "Senegal", se viu obrigado a definir seu trabalho em termos de melhoria nas condições, afirmando com evidente orgulho em 1923 que em Pernambuco "já não somos, senhores, um vasto hospital, mas um vasto sanitário, onde curam-se populações por día". ${ }^{47}$

Representações abertamente racializadas dos mocambos continuavam a existir. Discussões técnicas às vezes mal disfarçavam o preconceito. E a carga racial do mocambo já era alguma coisa tão arraigada - o imaginário social do mocambo de tal forma um imaginário negro - que não se fazia necessário explicitá-lo. No entanto, essas novas formas de pensar a diferenciação social chegaram a fomentar críticas radicais. Josué de Castro fornece um bom exemplo. No início dos anos 1930, ainda um médico recém-formado, Castro foi um dos "jovens apóstolos" a que Paulo Guedes se referia. Mais do que a maioria de seus pares, tinha trabalhado junto aos pobres, tanto como médico de fábrica quanto como pesquisador das condições de vida da classe trabalhadora. Mesmo assim, como muitos progressistas, Castro continuou a escrever sobre os brasileiros pobres - e sobre os afrodescendentes pobres, em particular - como se fossem um problema a ser resolvido; rejeitava o racismo biológico, mas não ignorava a cor, e se impressionava com o que via como fraqueza mental e física da classe trabalhadora mestiça do Recife:

Hoje ninguém mais afirma conscientemente que a mestiçagem seja a verdadeira causa da baixa vitalidade do nosso povo. O cruzamento do índio, do negro e do português não gera, por fatal hereditariedade, um mestiço débil, anémico e raquítico. Se a maioria dos mulatos se compõe de seres estiolados, com déficit mental e incapacidade física, não é por efeito duma tara racial, é por causa do estômago vazio. Não é mal de raça, é mal de fome. ${ }^{48}$

Em algumas ocasiões, Castro escreveu mais vividamente sobre os mocambeiros, mas sempre com um senso de distanciamento e exotismo. Num de seus ensaios, descreve um amanhecer de inverno tropical; grilos cantam, sapos coaxam, vendedores descalços emergem dos mocambos e sentem a lama entre os dedos de seus "pés chatos", enquanto equilibram cargas pesadas de frutas e legumes. Barzinhos abrem as portas para vender café, biscoitos ou cachaça. Soam os apitos das fábricas, trabalhadores saem para trabalhar, crianças "indiferentes ao frio e aos mosquitos" se jogam na lama "com gosto" para caçar caranguejos, os quais se alimentam de dejetos humanos para, em seguida, serem desmembrados e devorados. Castro jamais faz menção da cor ou da raça, mas os mocambeiros emergem como uma classe distinta de seres humanos, entranhada no mundo natural e envolta em 
necessidades animais. As primeiras tentativas do médico na direção de uma "interpretação histórica e económica à luz da bio-sociologia" objetivaram não afirmar a igualdade humana, mas identificar as causas profundas da diferenciação social. ${ }^{49}$

Logo, no entanto, os intensivos estudos nutricionais de Castro o levaram a situar a desnutrição crônica num contexto mais amplo. Já em 1936, ele destacava a necessidade de uma investigação sociológica do que seriam as "raízes profundas" dos mocambos no "latifundismo da cana", o que resultava em salários miseráveis e sufocava a diversificação da economia rural. Aqueles que não conseguiam sobreviver na zona do açúcar empreendiam uma "fuga" em massa para o Recife, onde vinham se juntar aos refugiados do sertão devastado pela seca; ambos os grupos gastavam $70 \%$ de sua renda insignificante numa alimentação inadequada, e mocambos pantanosos se tornavam para eles um refúgio urbano. ${ }^{50}$ Essa sequência de eventos, desenvolvida na escritos iniciais de Castro, tornou-se a espinha dorsal de A geografia da fome (1946), na qual o autor relacionava a privação nutricional à escravidão, ao monopólio da terra, à economia do açúcar e à fuga de refugiados rurais para cidades mal equipadas para thes dar ocupação fixa. A partir do final da década de 1930, Castro acrescentou ao seu trabalho intelectual a defesa de novas políticas sociais, primeiro ao servir no governo Vargas, depois como diplomata e diretor da Organização das Nações Unidas para Agricultura e Alimentação. No final da década de 1950, entrou de vez na política, defendendo uma reforma agrária radical no Congresso e escrevendo a partir de uma perspectiva crítica estruturalista e cada vez mais abrangente. Exilado após o golpe militar de 1964, morreu em Paris, advogando apaixonadamente até o fim pela eliminação da fome.

A maioria dos profissionais dedicados à questão do mocambo não chegou a ser tão revolucionária. Mas se uniu a Castro le a outros pensadores internacionais) na tentativa de entender esses assentamentos a partir de novas perguntas, priorizando causas estruturais e circunstâncias, e depreciando questões de raça, caráter ou cultura. A mudança ficou evidente num recenseamento pioneiro dos mocambos realizado pelo governo de Pernambuco em 1939, o qual, assim como as pesquisas nutricionais de Castro, não fez menção da cor dos mocambeiros. ${ }^{51} \bigcirc$ que comiam os pobres? Que doenças os tornavam fracos mental e fisicamente? Sabiam ler? Qual era sua estrutura familiar? Onde trabalhavam? Quanto ganhavam? Como iam para o trabalho? Qual era sua relação com as leis e as instituições do país? Foram essas as questões a nortear o conhecimento público sobre os mocambeiros do Recife e a reformulação gradual das políticas sociais, deslocando a culpa pela miséria dos ombros dos próprios pobres e colocando-a no corpo social como um todo.
49. Ibid., p. 21, 23, 78.

50. Ibid., p. 70-71, 82. A palavra "fuga", neste contexto, tem uma associação forte com o cativeiro.

51. Pernambuco (1939). 
52. Cf. Lira (1994; 1999b).

53. Cf. Sampaio (1927). Sobre Sampaio e Coutinho, cf. Lira (1994, p. 734-5). Sobre Coutinho, cf. Freyre (2004, p. 168-69) e Silva (2005). Para o argumento de Freyre sobre a superioridade do mocambo, Freyre (1937, p. 28-29).

54. Castro (1957) p. 72-73.

55. Cf. Freyre (1937).

56. Freyre (1967) p. $37-8$.

\section{REGIÃO E RAÇA}

Uma reavaliação diferente dos mocambos partiu dos chamados regionalistas - um grupo disperso de artistas, intelectuais, profissionais e figuras públicas que defendiam a especificidade nordestina e cristalizaram as noções de identidade mestiça que se tornariam o credo semioficial do Brasil. Para muitos regionalistas, o mocambo era para a arquitetura como o samba para a música: uma forma híbrida, com raízes na África, perfeitamente adequada ao clima e ao caráter particulares do Brasil. 52 Algumas das primeiras encarnações dessa concepção foram sugeridas por profissionais técnicos que não se incluíam entre os regionalistas, como o engenheiro Alde Sampaio e o estudante de medicina e urbanista amador Aluízio Bezerra Coutinho. Ambos saudaram as vantagens, do ponto de vista sanitário, de materiais naturais porosos que bloqueavam o calor e promoviam a circulação de ar, bem como elogiaram a racionalidade de uma arquitetura popular que utilizava matéria-prima e conhecimento locais. ${ }^{53}$ Muitos outros adotaram essa avaliação técnica, inclusive Josué de Castro, que escreveu em 1936 sobre as "qualidades higiênicas, fruto da experiência das populações primitivas do Nordeste" que tornavam os mocambos "um recinto muito mais confortável do que a maioria das casas de nossas cidades". ${ }^{54}$ Essa visão idealizada dos assentamentos como consequência natural de seu contexto climático e orgânico também aparece em representações artísticas idealizadas, notadamente numa série de esboços de Manuel Bandeira e Demetri Ismailovitch. ${ }^{55}$

Gilberto Freyre levou a análise regionalista dos mocambos mais longe. Já em 1926, o embrião do que se tornaria o "Manifesto Regionalista" se detinha no tema. Num elegante encontro em Versalhes, contava Freyre, o "tropicalista" francês Clemente de Grandprey relembrara sua visita de fins do século XIX a Pernambuco. Grandprey não mencionara os esquecíveis edifícios modernos do Recife - orgulho e regozijo da aristocracia local. Perguntara, em vez disso, sobre os mocambos da capital pernambucana. Por quê? "É que o mucambo se harmoniza com o clima, com as águas, com as cores, com a natureza, com os coqueiros e as mangueiras, com os verdes e os azuis da região como nenhuma outra construção". O mocambo tinha, portanto, mais valor do que qualquer imitação de forma arquitetônica:

Com toda a sua primitividade, o mucambo é um valor regional e, por extensão, um valor brasileiro, e, mais do que isso, um valor dos trópicos [...] pelo que representa de harmonização estética: a da construção humana com a natureza [...] pelo que representa como solução econômica do problema da casa pobre: a máxima utilização, pelo homem, da natureza regional $[\ldots]^{56}$ 
Uma década mais tarde, Freyre deu amplitude a essas reflexões em seu poético Mucambos do nordeste (1937). Nesse livro, e no mais conhecido Sobrados e mucambos (1936, segunda edição 1951), evocou os laços do mocambo com a África, a escravidão e a abolição. Elogiou sua aparência pitoresca, bem como o fato de serem construções pequenas e isoladas, o que incentivava que ali vivessem famílias nucleares e evitava a "vida em cortiço promíscua e ensardinhada". 57 Ao levar suas reflexões de 1926 a um novo patamar, Freyre também repreendia os urbanistas que buscaram erradicar o mocambo e sua herança ecocultural híbrida:

[...] a casa ideal para as regiões tropicais do Brasil não seria a que desprezasse o material empregado pelos indígenas e pelos africanos nem o seu plano de construção [...] Os que ingenuamente [...] vêm considerando o mucambo ou a palhoça o maior espantalho de nossa vida e querendo resolver o problema da habitação proletária no norte do Brasil, proibindo o uso da palha na construção de casas pequenas, vêm colocando o problema em termos falsos e inteiramente antibrasileiros e antiecológicos. $\bigcirc$ mucambo higienizado, com saneamento e piso, parece ser solução inteligentemente ecológica e econômica do nosso problema de habitação proletária $[\ldots]^{58}$

Tal visão divergia agudamente daquela adotada pelos sanitaristas e engenheiros do Recife. Freyre não pretendia impor hábitos eugênicos civilizados, nem desviar a atenção do pedigree étnico-racial dos assentamentos, ou tampouco resolver o "problema" do mocambeiro. Longe disso: celebrava o tipo de construção rústica que eram os mocambos e elogiava suas origens indígenas ou africanas, além de fervorosamente acreditar na higiene inata das classes populares brasileiras. Condenava as forças históricas responsáveis por depreciar os mocambos. $O$ imperialismo europeu disseminara o desprezo por culturas materiais nativas e seus padrões de consumo, e as estruturas econômicas imperialistas e escravocratas haviam relegado os mocambos a terrenos insalubres, privando-os de saneamento adequado e rebaixando as técnicas nativas de construção. ${ }^{59}$ Em Mucambos, e na segunda edição de Sobrados e Mucambos (1951), Freyre se esforçava para adaptar o modelo "ecológico" de Chicago ao contexto brasileiro. Ele exaltou o aspecto saudável dos barracos "trepados em pernas de pau sobre os alagadiços e os mangues", mas observou que:

[...] outros deixam-se ficar bem dentro da podridão, os moradores numa intimidade doentia com a lama [...] O problema é o ecológico, de distribuição humana desigual, o rico a estender-se pelo solo bom e seco, o pobre - ordinariamente mestiço, mulato ou negro - ensardinhado angustiosamente na lama. As populações miseráveis em luta com a lama muitas vezes acabam saneando o chão. Mas o chão enxuto e saneado é espaço aristocratizado: o mucambeiro é enxotado dele; e vem então ricos que levantam casas de pedra e cal. Casas de eira e beira. Os mucambos vão aparecer mais adiante, noutros trechos de lama $[\ldots]^{60}$
57. Freyre descreveu os mocambos rurais como "ninhos de gente" (1937, p. 21); para seu argumento acerca da superioridade do mocambo em relação ao cortiço, cf. p. 30-31.

58. Freyre (2004, p. 349). Sobre formação recíproca de culturas, cf. p. 298-99 e Freyre (1937, p. 21).

59. Sobre imperialismo, cf. Freyre (2004, p. 445).

60. Freyre (2004, p. 783). Aqui, Freyre desenvolve um trecho de Freyre (1937, p. 22-23), onde argumenta que, por sua simplicidade, o mocambo era ideal para os padrões de invasão, recessão e sucessão que a escola ecológica julgava fundamentais para os padrões da geografia social urbana. Em outro momento, ele defende que, ao transformar em "solo endurecido” as áreas pantanosas que geralmente lhes cabiam, os mocambeiros muitas vezes acabavam beneficiando os moradores mais ricos (1937, p. 32). Para uma análise de outros exemplos da influência da Escola de Chicago sobre Freyre, cf. Lira (1999a). 
61. Freyre (2004, p. 808).

62. Esses anos tumultuados são tratados na forma de ficção crítica por um marco do romance, $O$ moleque $R i$ cardo, de José Lins do Rego.
Esse movimento cíclico segregou as cidades brasileiras numa colcha de retalhos formada de "mocambos" e bairros "aristocráticos". Enquanto alguns descreviam as primeiras como "africanas" e os segundos como "europeus", Freyre argumentava enfaticamente que a divisão seria mais bem compreendida como entre "grupos", e não "raças". A escravidão trouxera o mocambo para o Brasil e determinara que a maioria dos mocambeiros seria afrodescendente. Mas a divisão social moderna - o abismo que tornava impossível imaginar o mocambo sem pobreza e miséria - se dava em outros termos, entre a "classe explorada com relação aos de classe - e não rigorosamente raça - exploradora". ${ }^{61}$

\section{MOCAMBOS E MOVIMENTOS SOCIAIS}

Freyre não era um radical de esquerda, mesmo no início da década de 1930. Porém, ao apontar a classe como a base da diferença social urbana, ecoava correntes políticas que alterariam radicalmente o discurso público sobre os espaços informais e seus ocupantes. Depois da "revolução" de 1930, Getulio Vargas e seus indicados políticos procuraram incorporar as classes trabalhadoras urbanas brasileiras às novas estruturas políticas, manobrando por realinhamentos populistas no país inteiro. Em parte, os getulistas agiam para contrabalançar os interesses conservadores das elites rurais exportadoras, que há muito dominavam a política brasileira, mas também buscavam evitar as investidas da esquerda, e particularmente do Partido Comunista, que penetrara em grau sem precedentes no Brasil urbano entre 1922 e 1935. No Recife, foi esse desafio político colocado pela esquerda que trouxe destaque à questão do mocambo.

Como berço de uma das poucas faculdades de Direito do Brasil, além de ser um importante porto e abrigar um significativo parque industrial regional, o Recife tinha uma longa tradição de ativismo de esquerda. Na década de 1910, anarcosindicalistas haviam fundado a Federação dos Trabalhadores de Pernambuco (FTB), ao passo que trabalhadores se organizavam em sindicatos nas indústrias de transporte, açucareira e têxtil. Uma greve geral varreu o Recife em 1919, e o recém-criado Partido Comunista instalou uma seção pernambucana em 1922.62 Em resposta, reformistas como Amaury de Medeiros passaram a defender intervenção estatal em questões de moradia, pobreza e condições de trabalho. Medeiros deixou claro o caráter reacionário de seu trabalho na saúde pública numa entrevista em 1924, ao mencionar a ameaça vermelha e sugerir que doença 
e ignorância a alimentavam: para ele, "a higiene e a instrução são os elementos essenciais para esta obra de defesa dos nossos legítimos interesses de elite". ${ }^{63}$

Sob seu comando, a Diretoria de Saúde e Assistência Social instituiu refeitórios populares, dava assistência jurídica a trabalhadores acidentados, oferecia um número limitado de moradias subsidiadas e montou uma agência de empregos. ${ }^{64}$ Essas iniciativas esparsas pouco fizeram para conter a esquerda que se organizava e avançou consideravelmente nos anos turbulentos que se seguiram à Revolução de 1930 de Vargas. Em 1935, os comunistas formaram a segunda maior bancada nas eleições municipais do Recife. Os vereadores só foram impedidos de assumir seus mandatos pela onda de repressão subsequente ao levante comunista de 1935, particularmente violenta no Recife. ${ }^{65}$

Desde o começo, habitação e serviços públicos urbanos figuraram com destaque na agenda dos movimentos operários e populares de Pernambuco. Em 1914, a anarcossindicalista FTB já pedia aluguéis baixos e casas baratas, e nos anos 1920 - Diário do Povo manifestou sua esperança de que o alto custo da moradia desencadearia uma rebelião violenta. ${ }^{66}$ No final daquela década, os comunistas começaram a fazer incursões aos mocambos, onde viam abundante oportunidade de recrutamento. Concentrando uma população de trabalhadores pobres, constantemente ameaçados de remoção forçada e necessitados do tipo de ajuda legal, organizacional e até médica que os militantes eram capazes de fornecer, mocambos e favelas rapidamente se tornaram lugares onde um jovem Partido Comunista podia começar a obter adesão real daquelas pessoas por quem alegava lutar.

De início, os comunistas atuavam principalmente junto a pequenos grupos de vizinhos. Organização parecida existira nos mocambos por décadas, com origens e inclinações ideológicas bastante variadas. Em muitos casos, os grupos começavam por a iniciativa de ativistas católicos como Frei Casemiro, um franciscano nascido na Alemanha que ficou conhecido como o "apóstolo dos mocambos". ${ }^{67}$ Noutros, respondiam à ameaça de despejos ou à necessidade de fomentar apoio a um chefe ou político local. Havia também situações, especialmente a partir de 1920, nas quais o objetivo era pressionar por serviços urbanos essenciais, ou por postos de saúde e escolas. E havia ainda iniciativas culturais para promover as religiões afro-brasileiras e festas populares como o Carnaval. Assim como no caso mais bem documentado do Rio, esses grupos também podiam servir como canais para o ativismo político. ${ }^{68} \mathrm{~A}$ maioria das organizações acabaria combinando esses elementos, tornando-se a um só tempo a mais efetiva defesa local dos mocambos e campo de intensa batalha por influência ideológica, política e até econômica sobre as comunidades pobres.
63. Cf. Lopes (2003)

64. Melo (1985, p. 48-49).

65. Sobre comunismo (e cultura popular), Gominho (1998, p. 50-51). Numa das batalhas de 1935, no Largo da Paz, em Afogados, mais de 700 pessoas morreram.

66. Melo (1985, p. 49, 51).

67. Cf. Teves (1948); Gominho (1998, p. 44-46).

68. Sobre o Rio, cf. Fischer (2008) e Guimarães (2009). 
69. Bezerra (1965, p. 41). Essa organização surge nas memórias de ativistas dos movimentos populares urbanos nos anos 1970: cf. História do movimento de bairro... (1987).

70. Cavalcanti (1998, p.168).

71. A Marinha tinha sob seu domínio todas as terras costeiras estratégicas. Isso facilitava a proliferação de mocambos: embora com frequência tomadas, tais propriedades não podiam ser vendidas e eram muitas vezes ocupadas ilegalmente, especialmente quando o "terreno" se resumia, na verdade, a um trecho aterrado de mangue.

72. Em 1913, 2.030 das 3.110 moradias do distrito eram mocambos e outras 413, casas de pau a pique; em 1923, 5.979 eram mocambos ou pau a pique, contra 4.697 casas de alvenaria. Cf. Recife (1915)

73. Sobre a história da Vila São Miguel como um dos primeiros projetos habitacionais patrocinados pelo governo no Brasil (administrado pela Fundação da Casa Operária de Madeiros), cf. Melo (1985, p. 49-51).

74. Arquivo Público Estadual (APEJE), Fundo SSP, n. 420, Prontuário 260 , arquivo \#1.
A maioria desses grupos deixou poucos traços históricos; testemunhas orais documentam períodos posteriores, e os arquivos da polícia política geralmente não contêm muito mais do que avisos sobre reuniões, panfletos ou recortes avulsos de jornais. No coração do Recife, porém, um grupo se posicionou de forma particularmente aberta e persistente, fundando uma organização chamada a Sociedade a Bem da Nossa Defesa, mais tarde rebatizada como a Liga Mista dos Proprietários Pobres de São Miguel. ${ }^{99}$ Os registros policiais sobre a liga iluminam tanto as técnicas de organização e redes que sustentavam essas iniciativas quanto as maneiras pelas quais tais atividades forçaram uma mudança radical no discurso e nas políticas voltadas aos mocambos.

A Vila São Miguel era uma pequena vizinhança localizada em Afogados - o nome do bairro era, por sua vez, uma referência macabro às muitas pessoas pobres e escravizadas que pereceram ao atravessar o rio Capibaribe a pé na maré alta. ${ }^{70} \mathrm{~A}$ área compreendia mangues e muita propriedade da Marinha, criando as condições ideais para a proliferação dos mocambos: localização central, terrenos alagados e obstáculos legais à especulação formal. ${ }^{71}$ Afogados era o bairro mais populoso do Recife e a maioria de suas moradias era de mocambos: 2.030 das 3.110 em 1913 (65\%) e 5.979 de um total de 10.676 em 1923 (56\%).72 A Vila São Miguel começou a ser instalada em 1924 como uma das tentativas de Amaury de Medeiros para combater os mocambos, mas o número de construções informais rapidamente se sobrepôs ao do núcleo da ocupação oficialmente autorizado. ${ }^{73}$

A disputa por terra em São Miguel começou de maneira típica e, também tipicamente, se tornou violenta e complicada. A briga teve início quando certo Ladislau do Rego vendeu "seus" direitos de arrendamento dos terrenos a uma empresa chamada Eduardo Santos \& Cia., provavelmente algum tempo antes de 1930. Seguiram-se o litígio, a ameaça de despejo e a reação da liga a essa ameaça. Oficialmente, a disputa era estritamente legal: o advogado da liga argumentou que São Miguel era propriedade da Marinha e não estava sujeita a "foro". Mas o caso extrapolou para muito além dos gabinetes da Justiça, muitas vezes com violência. Os líderes da liga acusaram Eduardo Santos, juntamente com seus "protetores" no governo, de "violências terroristas" - de destruir mocambos, descrever os membros da liga como "ladrões, desordeiros e subversivos" e usar seus poderosos aliados para "impatrioticamente violar as leis amparando os interesses dos aventureiros". ${ }^{74}$ As queixas quanto a violência e corrupção política prosseguiram até 1935: numa carta ao jornal comunista Folha do Povo, os moradores reiteraram as acusações de brutalidade e alegaram que a prefeitura se recusava a permitir que construíssem ou reformassem os mocambos se não desembolsassem um aluguel mensal de cinco mil- 
réis pagos aos "falsos proprietários" dos terrenos, mesmo sendo impossível a eles ter "direito à terra" porque ela pertencia "à Marinha Nacional" . ${ }^{75}$

Desde o início a liga mostrava elevada consciência legal e política, embora não esteja claro o quanto isso foi fomentado por líderes militantes. ${ }^{76}$ No começo da década de 1930, um grupo de "chefes de numerosa família" escreveu ao "chefe" da 7 a Região Militar de Pernambuco implorando para que intercedesse "perante a autoridade competente" para que a prefeitura thes concedesse uma licença para "concertos necessários" nos seus mocambos, o que tinha sido negado sob "a alegação de que o terreno [...] estava em litígio". ${ }^{77}$ Não se sabe se a iniciativa deu resultados, mas os moradores expunham ali seus argumentos competentemente em termos legalistas. Apelavam ao comandante por se tratar de disputa por lotes da Marinha. Também enfatizavam o fato de já habitarem aquelas casas "há longos anos" e de as terem construído eles próprios, ambos pré-requisitos essenciais para obter o direito legal de posse. ${ }^{78}$ A linguagem da carta se assemelhava à de inúmeros apelos do tipo na era Vargas, destacando o status dos requerentes como cidadãos brasileiros e chefes de família e elogiando o comandante como alguém que "encara esses problemas sociais com devotado carinho, amparando sempre os direitos dos mais fracos contra a prepotência dos mais fortes" ${ }^{79}$

No entanto, os líderes de São Miguel não se contentaram em reivindicar seu direito apenas por canais oficiais. Já em 1931, a liga solicitou a ajuda e assistência da União Geral de Trabalhadores de Pernambuco (UGTP), uma das organizações operárias de esquerda mais longevas do Recife. $\bigcirc$ presidente e o secretário da liga explicaram que ela havia sido "fundada para combater a exploração contra os trabalhadores dessa localidade concernente no pagamento dos terrenos que ocupam esses 700 mocambos". ${ }^{80}$ Em seguida, pedia conselhos e orientação da União. A promessa de que ambos seriam concedidos foi feita pela UGTP em linguagem floreada:

[...] tendo o vosso apoio de trabalhadores conscientes que sois esperamos transformar vossa sociedade em um verdadeiro paladino pela liberdade desse pequeno pedaço de terra que reconhecemos pertencer a todos trabalhadores dessa Villa em geral, pois companheiros e companheiras, ingressai as fileiras de vossa Liga que sereis vitoriosos e se assim fizerdes estareis cumprindo com o vosso dever em lutar pelo bem comum. ${ }^{81}$

Alguns meses mais tarde, a liga fez seu registro em cartório. A linguagem eclética do documento de fundação misturava preocupação com questões de propriedade local, retórica progressista cosmopolita e intenso legalismo, reforçando a impressão de que os organizadores ocupavam um vasto espectro ideológico. A liga pretendia "congregar debaixo de uma só bandeira, sem fazer distinção de cor,
75. Exploração brutal contra... (1935); cf. também Revoltante atitude da... (1935).

76. Bezerra (1965, p. 41) observa que os estatutos dessas "sociedades" eram muito semelhantes e demonstravam alto grau de "consciência de classe", e ambos sugerem uma ampla participação de ativistas políticos no trabalho de organização.

77. Cf. APEJE, Fundo SSP, n. 420, Prontuário 260, arquivo \#1 [s.d.].

78. Sobre as bases legais para reivindicações de propriedade no início do século XX no Brasil, cf. Fischer (2008), capítulo 7.

79. Cf. APEJE, op. cit.

80. Ibid.

81. Ibid. 
82. Ibid.

83. Ibid.

84. Ibid. Comunicado ao Secretaria da Segurança Pública, Delegacia de Vigilancia Geral e Costumes, 31 May, 1941, de Pedro A. Neves, Guarda Civil de 1a Classe

85. Cf. Fischer (2008). nacionalidade, credo político ou religioso, todos os proprietários pobres da citada Villa". ${ }^{82}$ Os membros pagavam uma taxa e a organização funcionava democraticamente. A Liga também buscava reforçar o respeito pelas pessoas e pela propriedade, envolvendo a polícia quando necessário. Procurava controlar rigorosamente os atos dos moradores na luta contra os despejos e prometia benefícios apenas aos membros pagantes. A filiação chegava a mais de mil famílias, a maioria da população local. A liga planejava abrir uma caixa beneficente e criou ainda uma escola, que oferecia cursos de alfabetização para adultos e instrução para meninos e meninas.

A Secretaria de Segurança Pública deu permissão à liga para funcionar, mas a vigiava de perto. Os membros diligentemente submetiam mudanças de liderança e comunicados sobre reuniões à polícia política. Contudo tais gestos eram muito pouco para apaziguar os agentes, especialmente diante de acusações como a de um morador insatisfeito que, num bilhete mal traçado, apontou a liga como uma "sociedade di comonista [sic]". A nota divulgou os apelidos de vários membros (um deles era chamado de "pinga fogo") e alegava que qualquer morador que não quisesse fazer parte da organização corria risco de ser "asacinado". A polícia políitica acusou pelo menos um dos líderes de ligação com os comunistas, além de afirmar ter encontrado um folheto marxista em espanhol numa busca realizada no assentamento. ${ }^{83}$ A liga anunciava seus encontros em linguagem estridente e impregnada de consciência de classe, enquanto os moradores levavam a público suas queixas em cartas à comunista Folha do Povo.

No longo prazo, São Miguel sobreviveu - a sede da liga continua de pé e funcionando até hoje - e pelo menos alguns de seus residentes acabaram conquistando direitos de posse e permanência. Esses direitos foram obtidos na sequência de uma considerável batalha política e possivelmente só depois de um expurgo dos membros comunistas da organização. Em 1937-1938, a liderança mudou abruptamente, e a liga de repente passou a ter apoio do governo. Em 1940, foi autorizada a entrar para a Liga das Sociedades Beneficentes de Pernambuco. No mesmo ano, a nova liderança foi acusada de corrupção e exploração de outros moradores. Talvez fosse verdade - defesa e exploração com frequência se misturavam na política do mocambo -, mas também é possível que tenha sido uma desculpa para promover expurgos na organização. ${ }^{84}$

A história da luta da liga é interessante por si só, se mais não fosse porque organizações semelhantes surgiram em todo o Brasil durante aqueles anos. ${ }^{85}$ Para os propósitos deste artigo, esses eventos são de grande relevância pela mudança que forçaram no discurso e na política do mocambo. Em seus panfletos e cartas, os moradores invariavelmente surgiam associados com trabalho, nação ou 
família: "chefes de numerosa família", "cidadãos brasileiros", "patrícios devotados", "trabalhadores", "proprietários pobres", "moradores". Sua luta sempre parecia ser pacífica. Enquanto seus oponentes os chamavam de "subversivos" e os submetiam a violência e prisões arbitrárias, eles enfaticamente situavam suas ações dentro dos limites legais. Não glorificavam os mocambos, mas destacavam o fato de os terem construído eles próprios, de viverem neles há muitos anos e não disporem de outra opção de moradia. Seus adversários, por outro lado, eram apresentados como "exploradores" que lançavam mão de falsas alegações e tentavam usar conexões pessoais para subverter o sistema legal.

Esses materiais eram talhados para o seu público e provavelmente incorporavam forte influência de ativistas de fora do mocambo. Enquanto alguns, evidentemente, tinham como autores pessoas pobres e pouco alfabetizadas, outros eram floreados e elaborados, com ênfase em objetivos - unidade "sem fazer distinção de cor, nacionalidade, credo político ou religioso", escolas livres de religião ou punição corporal - que constituíam prioridades para progressistas cosmopolitas.

Ainda assim, era a maior organização de bairro de que se tem registro, e a maneira pela qual os moradores se apresentavam - ou se deixavam apresentar - merece atenção. Não fazemos ideia do significado que os mocambeiros de São Miguel davam a suas raízes africanas - ou, antes, de quantos entre eles eram afrodescendentes, embora afirmar que eram maioria provavelmente seja um palpite seguro. ${ }^{86} \mathrm{~A}$ forte presença do maracatu na região sugere considerável identificação com a cultura afro-brasileira e, na sua busca por subversão política, a polícia políitica encontrou, junto com tratados marxistas, um documento com referências a religiões afro. ${ }^{87}$ Porém, na documentação da liga, os mocambos não foram descritos como lugares "africanos", fosse no sentido pejorativo, fosse na iteração pitoresca e exótica de Freyre e seus parceiros regionalistas. Tampouco os mocambeiros eram descritos como vítimas miseráveis, alijadas pela desnutrição e pelas doenças. Eram brasileiros orgulhosos que se definiam principalmente por sua pobreza digna. Acreditavam ter direito a um naco da cidade e estavam preparados e dispostos a lutar contra a "exploração". Ao permitir que essa fosse a caracterização dominante, os moradores do mocambo talvez tenham silenciado ou ocultado sua consciência e identidade raciais, impedindo o potencial desenvolvimento de uma solidariedade política antirracista, mas essas caracterizações também podem ser contextualizadas historicamente e vistas de forma diferente: como uma espécie de otimismo acerca das possibilidades transformadoras da solidariedade de classe, da cidadania e da urbanização.
86. Nenhum dos levantamentos publicados sobre os mocambos do Recife fornece informações relativas à cor dos mocambeiros.

87. Sobre maracatus, cf. Lima (2010) e Lima; Guillen (2007). 
88. Trabalhador, ocupa teu... (1935).

89. As eleições municipaes... (1935).

90. Sobre a Folha, cf. Nascimento (1962, p. 344-371).

91. Braga (1935). "Recife, tome cuidado", de junho de 1935 e também de Braga, imerge ainda mais na miséria física dos mocambos, além de prenunciar a revolução; publicado em Braga (1936, p. 110-112).

\section{COMUNISMO E CONSCIÊNCIA}

Os intelectuais comunistas ampliaram essa orientação em vários fóruns públicos. A questão do mocambo era a pedra de toque de "Trabalhador, ocupa teu posto!", uma plataforma política da esquerda que ganhou apoio eleitoral significativo em 1933 e 1935. Nessa segunda ocasião, os mocambos puxavam a lista de "demandas populares". Candidatos prometeram lutar por licenças gratuitas para construção e reformas, isenções fiscais para ocupantes-proprietários, distribuição de terras saneadas para moradias de baixa renda e serviços públicos como eletricidade, fontes de água e sanitários coletivos. ${ }^{88} \mathrm{O}$ gráfico, jornalista e candidato Antônio Carlos Chagas Ribeiro identificou nos mocambos o tipo de problema que "gritava" por representação proletária na Câmara de Vereadores, pois pela boa vontade burguesa nunca seria resolvido. ${ }^{89}$

Intelectuais da esquerda consolidaram tais visões na Folha do Povo, um diário que durou de julho de 1935 até o levante comunista, no final de novembro. Rubem Braga - carioca que se tornaria um dos melhores cronistas do Brasil - editou o jornal, para o qual contava com artigos de Gilberto Freyre, Josué de Castro, Aderbal Jurema e Carlos Lacerda. ${ }^{90}$ Os mocambos figuravam com destaque nas páginas da Folha, onde se tornaram emblemas de sofrimento físico, corrupção governamental, democracia incompleta, abuso brutal de pessoas e exploração de classe. Num artigo, Rubem Braga evocou o retrato de Josué de Castro, em que a pobreza implicava uma intimidade indecente com o mundo natural: "O caranguejo é patrício do pobre. A lama é a pátria do caranguejo, do pobre, do urubu e do porco". Esse estado de coisas não era resultado inevitável da fome e das doenças. Tudo tinha origem no desemprego e na escravidão assalariada, assim como tinha solução com a consciência de classe:

Como todos os aliados dos ricaços, o caranguejo não é bastante forte para defender os exploradores quando soar a hora. Senhores, o povo da lama está cansado de caranguejo. Ele sabe que além do caranguejo existe a vida. Ele não se contenta mais com o caranguejo. Ele quer também a vida. Nestas horas de opressão e miséria o caranguejo é amigo do pobre. O pobre também será amigo do caranguejo. Ele deixará o caranguejo em paz, ele sairá da lama, pátria do caranguejo. E virá para a terra de onde foi expulso, para a terra que é sua. E os caranguejos viverão em paz nos seus mangues fétidos [... $]^{91}$

Outros artigos elencavam as promessas não cumpridas de "democracia" e as usurpações da lei e do poder que levavam à existência dos mocambos. Os assentamentos nasciam da pobreza estrutural, mas a doença e a fome de seus moradores também resultavam da crua exploração de pessoas, muitas vezes sob 
conivência oficial. A maioria dos mocambos, dizia o jornal, começara como construção espontânea: uma ou algumas famílias se instalando em terrenos da Marinha, gradualmente ocupando a lama, atraindo cada vez mais residentes, criando, enfim, uma pequena comunidade. Aí chegavam os exploradores, reivindicando a terra, exigindo aluguel, exercendo violência sem controle contra qualquer um que resistisse. ${ }^{92}$

Um dos piores entre os exploradores, na opinião do jornal, era Manuel d'Oliveira Mostardinha, "senhor feudal de um povoado de lama". O domínio epônimo de Mostardinha contava cerca de 2.000 barracos numa baixada dos Afogados. Habitado por trabalhadores pobres, muitos dos quais desempregados pela crise econômica, o local foi abandonado pelo Estado em todas as áreas relevantes: "Justiça não há. Educação não há. Higiene, não há". $\bigcirc$ governo oficial foi substituído pelo de Mostardinha, gerido à base de uma caderneta que o jornal apelidou - em irônica referência à nova Carta brasileira - de "Constituição" do Mostardinha. Essa pequena caderneta, uma janela fascinante para entender a regulamentação informal vigente nos espaços mocambeiros, especificava que a terra sobre a qual os mocambos estavam construídos pertencia a Mostardinha e que nenhuma transação envolvendo a terra ou os barracos teria validade sem sua aprovação. ${ }^{93}$ Não se admitia atividade comercial ali, tampouco pagamentos de aluguel atrasados ou malfeitores. Aqueles que violassem essas regras teriam seus mocambos confiscados e seriam sumariamente expulsos. Com essas disposições, o livreto exigia dos residentes que observassem um sistema regulatório alternativo, pelo qual perdiam qualquer direito às garantias básicas que o direito civil oferecia a inquilinos ou até a posseiros, e que concedessem a Mostardinha poderes regulatórios normalmente reservados ao governo local. A única concessão de Mostardinha ao sistema legal estabelecido era uma certa indulgência quanto à intervenção policial - embora, conforme explicou um morador, isso se devesse apenas ao fato de que "Mostardinha e polícia é uma coisa só". $\bigcirc$ jornal acabou relacionando os abusos de Mostardinha às formas brutais de dominação rural que tantos moradores da cidade denunciavam: "Esses Mostardinhas provam que não é só o interior: na capital [...] aqui em Recife subsistem locais de domínio feudal!"94

Em todos esses relatos, os intelectuais comunistas colocavam o mocambo no contexto da desigualdade social, fazendo uso de uma linguagem que se tornava familiar. A comunhão miserável e perversa dos mocambeiros com a natureza era circunstancial, e não alguma coisa inerente. Era o resultado de profundas distorções históricas da economia, da sociedade, das leis e da política no Brasil. Para os comunistas, no entanto, não bastava reconceituar os mocambos de fora, na esperança de que recebessem melhorias benevolentes. Buscavam também mudar as categorias pelas quais os próprios mocambeiros entendiam a desigualdade e, portanto, sua
92. Cf. Vivendo na lama... (1935).

93. O livreto exigia que as transferências de propriedade fossem anotadas, o que faz dele um diário das transações informais para cada lote de "propriedade" de Mostardinha. Segundo a lei brasileira, terra e benfeitorias podiam ser negociadas separadamente, e os inquilinos tinham direito a uma compensação por "melhorias" realizadas no imóvel alugado; a caderneta exigia dos inquilinos que renunciassem a esses direitos.

94. Cf. Mostardinha - senhor feudal... (1935), Expoliado por Mostardinha... (1935) e Filantropia de Mostardinha (1935). 
95. Cf. Tavares (1935).

96. Cf. Braga (1935).

97. Cf. Tavares (1935) superação. E, num país em que menos de meio século antes ainda havia escravidão, essa reconceituação envolvia necessariamente a questão da consciência de raça. Em geral, os comunistas tratavam do tema indiretamente, ao relatar a transição da escravidão para a escravidão assalariada e se referir aos mocambos como as novas senzalas. Mas, num artigo curioso, o jornalista Cláudio Tavares tornou a posição comunista mais clara, descartando a consciência de raça como coisa do passado e evocando os mocambos como espaço de vanguarda no qual a miséria comum a todos forjava a classe no cruzamento das origens raciais e regionais. ${ }^{95}$

artigo começava relatando um momento de quebra de tabu: um homem negro, "José Santana", infringira todos os códigos de polidez para fazer um elogio indireto a Tavares: "Eu julgava o senhor um brancoso tão besta! Agora é que estou vendo que me enganei." Para o jornalista, aquele comentário abria a porta para uma franqueza paternalista no tema da raça e exploração econômica:

É bom que você tenha se enganado, porque desse jeito eu posso falar mais à vontade com você. Posso-the dizer que essa história do preto e brancôso, branco e pretôso, não existe mais. Antes do 13 Maio, existia. Depois desapareceu. Não foi a escravidão que desapareceu. Foi a questão de raça. ${ }^{96}$

Segundo Tavares (que era branco), com a escravidão legalmente encerrada, a raça se tornava apenas uma cor, não mais a base de qualquer diferença significativa. E era vital que os pobres do Recife criassem nos mocambos uma nova consciência da desigualdade:

Assim devem ser os homem [sic] dos mocambos. Todos devem ser iguais. A cor não deve ser levada em conta. Nem cor religiosa, nem nenhuma. Todos devem ser apenas uma coisa única: homens dos mocambos. Homens de mocambos quer dizer homens pobres, que trabalham demais. Quem não tem instrução porque os homens das casas de portas pintadas não deixam. Não têm higiene pela mesma razão [...] É a tal questão em que a cor não interessa. $\bigcirc$ que interessa são as classes. As classes são duas: explorados e oprimidos, a primeira; a outra exploradores e opressores [...] Quem não é explorado é explorador; quem não é opressor - é oprimido. $\bigcirc$ meio termo não deve existir. É... apenas ilusão. ${ }^{97}$

As esperanças comunistas na via eleitoral até o poder desmoronaram em novembro de 1935, quando seu fracassado levante justificou um expurgo políitico nacional. No entanto, a reconceituação dos mocambos encontrou sua expressão mais acabada após a revolta, num romance de Antônio Carlos Chagas Ribeiro publicado em 1936. O romance em si, Mocambos, é uma fábula moralizante, escrita em linguagem empolada e muitas vezes misógina. Nela, um gráfico e mocambeiro chamado Antônio funda uma associação muito parecida com a Liga de 
São Miguel. No entanto, vítima de advogados negligentes, a organização perde sua causa na Justiça e, a partir daí, os moradores, se quisessem continuar em seus barracos, seriam obrigados a pagar aluguel a um falso "proprietário". Sob alegação de que pretendia construir uma igreja na propriedade, o "dono" expulsa Antônio e outros líderes da associação; Antônio quer resistir, mas sua esposa o trai e eles são forçados a se mudar para outro assentamento. Lá, cegada pela ambição social e por uma falsa fé católica, a esposa rejeita os companheiros proletários de Antônio e coloca a filha no caminho da perdição ao se aproximar da senhora exploradora da propriedade, cujo filho seduz e depois abandona a moça. Quando Antônio morre num acidente de bonde, a mulher se dá conta do rumo errado que tomou, mas é tarde demais: perdeu o mocambo que Antônio havia trabalhado tão duro para conquistar, jogou fora a amizade dos companheiros do marido e é obrigada a deixar o mocambo "sem rumo, sem amparo, para a prostituição ou para a morte". ${ }^{98}$

Independentemente de suas qualidades literárias, Mocambos marcou um ponto de partida no debate público sobre a informalidade urbana. Chagas Ribeiro tinha a óbvia intenção de exaltar a solidariedade de classe e a organização política populares, tarefa particularmente importante para a esquerda depois da dura repressão sofrida em 1935. No entanto, em seu extenso detalhamento da vida no mocambo, o romance também serviu para dar mais visibilidade às caracterizações dos assentamentos que apareciam nos documentos da liga e na Folha do Povo. Os mocambos não são um paraíso pastoral - sofrem com enchentes, doenças e falta de higiene. Os moradores acabam indo parar ali porque são vítimas de estruturas sociais injustas. Expulsos do sertão pela seca e dos canaviais pela exploração brutal dos senhores, desembarcam no Recife e são obrigados a aguentar as condições do mocambo por causa dos baixos salários e de exploradores que alegam posse da terra. Porém, os mocambos também são lugares necessários, onde os moradores podem viver com dignidade apesar de suas privações, abrindo caminho feito "bandeirantes" na luta pela a solidariedade de classe e a emancipação urbana.

A questão racial não fica totalmente ausente. Chagas Ribeiro descreve os protagonistas como "pardos" e afrodescendentes. A religião e a cultura popular africanas são um pano de fundo distante, como no final do livro, quando a batida constante do Xangó pontua a despedida da esposa e da filha. Contudo, são traços incidentais, antes superestrutura do que estrutura. Numa passagem que ecoa Cláudio Tavares, Chagas Ribeiro escreveu: "Tudo aquilo devia se parecer com a África ou com as cabanas dos indios; no entanto, ali estava apenas o lugar onde habitavam os proletários dessa grande cidade industrial que é Recife". 99

Mocambos é um livro menor, mas encapsulou uma onda de atividade política (ao menos em parte popular) que influenciaria muito as políticas públicas no Recife. 
100. Para uma biografia mais completa, cf. Pandolfi (1984).
Os assentamentos não podiam mais ser descritos apenas como lugares "africanos" exóticos ou atrasados, ou como redutos de doença e fome esperando por uma salvação que viria da tecnocracia. Não eram simplesmente emblemas de uma identidade brasileira mestiça. Os mocambos eram lugares onde identidades de classe podiam se formar e demandas políticas emergiam em termos universais por soluções quanto a injustiças estruturais e conduta ilegal. Na esteira do levante fracassado de 1935, havia pouca chance de que os mocambos explodissem em fervor revolucionário. No entanto, a sensação era, e não apenas no Recife, de que aqueles assentamentos podiam ser politicamente significativos, e de que as demandas de seus moradores precisavam ser tratadas conforme eles mesmos as propunham.

\section{AS LINGUAGENS DA DESIGUALDADE E A LIGA SOCIAL CONTRA O MOCAMBO}

A parte final deste artigo recupera os modos pelos quais conceitualizações concorrentes da desigualdade e da justiça social influenciaram as políticas habitacionais, num momento em que a informalidade urbana pela primeira vez ocupava o centro da arena política no Brasil. Começa no final de 1937, quando o então ditador Getúlio Vargas nomeou Agamenon Magalhães como governador de Pernambuco. Magalhães era nativo do interior do Estado: descendente de um clã político, formou-se advogado e atuou como promotor e congressista antes de assumir (simultaneamente) os cargos-chave de ministro do Trabalho e da Justiça de Vargas. ${ }^{100}$ Nesses postos, Magalhães criou as bases para mais de meio século de políticas trabalhistas populistas, ao mesmo tempo que se estabeleceu como um nome de oposição contumaz à influência comunista sobre a organização dos trabalhadores.

Magalhães tinha muito com que se ocupar no retorno a seu estado natal. Bandidos vagavam pelo sertão; as vítimas da seca lotavam cidades pequenas e grandes; a indústria açucareira vivia em perpétua crise. Sua missão maior era estender o populismo corporativo de Vargas ao Nordeste, muitas vezes enfrentando feroz oposição. A principal prioridade urbana de Magalhães, à qual dedicou extraordinária energia política, foi uma campanha massiva para erradicar os mocambos do Recife. Casebres e favelas já haviam muitas vezes sido postos abaixo em todo o Brasil. Com frequência as autoridades proibiam os mocambos e outras moradias "insalubres". No entanto, a Liga Social Contra - Mocambo de Magalhães era um empreendimento inovador: uma campanha governamental maciça e integrada que combinava remoções violentas com recenseamentos, educação pública e habitação subsidiada. Como tal, é 
particularmente útil para observar como e por que as novas linguagens da desigualdade social surgidas em torno dos mocambos nos anos 1930 passaram a definir debates sobre a pobreza urbana brasileira no século XX.

A liga lançou sua ofensiva em julho de 1939 com uma blitz multimídia. Magalhães era, convenientemente, dono de um jornal - a Folha da Manhã - e encheu suas páginas de propaganda pró-liga. ${ }^{101}$ Os censores da Era Vargas silenciaram a oposição em outros veículos, e um enorme recenseamento dos mocambos - o primeiro do tipo a ser feito no Brasil - forneceu embasamento empírico sério ao trabalho da organização. Magalhães fez reuniões com membros da alta sociedade, muitos dos quais abraçaram publicamente a campanha. No entanto, de modo tipicamente corporativista, o governador também buscou a inclusão de um amplo espectro de setores sociais organizados, incluindo profissionais médicos e sanitários, "vendedores ambulantes", "estudantes universitários" e grupos de trabalhadores ligados à Igreja Católica. ${ }^{102}$ Magalhães reuniu ainda "donos" de mocambos e de terrenos nos assentamentos, oferecendothes participação na formalização das moradias de baixa renda. Até o famoso Mostardinha se integrou. ${ }^{103} \bigcirc$ governador incentivou audiências públicas nos mocambos, escreveu incansavelmente em defesa da campanha, comandou transmissões radiofônicas, incentivou um repórter da Folha a escrever um romance sobre o tema e patrocinou uma peça que promovia as visões da Liga. ${ }^{104}$ Em todas essas instâncias, Agamenon e seus aliados procuraram convencer a população do Recife de que os assentamentos representavam uma calamidade social e moral. Ao anunciar a formação da liga, Magalhães escreveu: "Temos que considerar o problema como se tivesse havido um terremoto e as 164837 pessoas que habitam os mocambos ficassem ao relento. Vamos recolher os salvados da catástrofe." 105

No dia seguinte, ele retratava a luta da liga como equivalente à luta mítica (e historicamente distorcida) dos abolicionistas brancos recifenses:

Diante, pois, do mocambo, haverá uma sensibilidade que não estremeça, ou uma consciência que não proteste? Ha quem fique, diante de tamanho perigo social, de braços cruzados? Ha quem tenha o coração tão duro que se feche ao apelo do governo para fazer uma casa e derrubar um mocambo? Onde estão as mulheres que vendiam as suas joias para comprar a liberdade dos negros? Onde se esconde a grandeza varonil dos fidalgos pernambucanos, que se despojavam de honrarias e de bens para lutar pelo direito dos outros? Não ha opressão social mais cruel do que a do mocambo. ${ }^{100}$

Em resposta a essa opressão, Magalhães exigia "solidariedade cristã" e sacrifício compartilhado, um argumento que ele reforçava elogiando indivíduos de todas as classes sociais que abriam mão de suas casas e lucros em prol da campanha. ${ }^{107}$
101. Sobre a Folha da Ma$n h \tilde{a}$, cf. Pandolfi (1984, p. 52).

102. Cf. Reune-se amanhã a... (1939).

103. Cf. Reune-se amanhã a... (1939).

104. O romance é $M o c a m b o$ de Antonio Barreto; Magalhães assina a introdução. A peça, Mocambo, de Valdemar de Oliveira e Filgueira Filho, foi encenada pela primeira vez em 1939 e publicada pela Imprensa Oficia em 1940. Também contou com uma introdução de Magalhães, que havia indicado Oliveira para a direção do Teatro Santa Isabel. Oliveira defendeu medidas ambiciosas de saúde pública na década de 1920; é autor de um relato elogioso sobre Amaury de Medeiros, bem como de um livro sobre saúde pública e educação.

105. Magalhães (1939g).

106. Magalhães (1939h).

107. Cf. Magalhães (1939i), que conta a história de um pobre ex-cabo da polícia que durante uma década investiu tudo que tinha na construção de cinco mocambos nos mangues de Gamalleira, e depois os entregou à campanha. 
108. Cf. Magalhães (1939a); Campello (1939).

109. Barreto (1939, p. 29-30, 43-44). Houve extensas campanhas contra as religiões afro-brasileiras no Recife durante o Estado Novo.

110. Cf. A Estatística... (1938), Mortalidade infantil... (1939). Lira (1999b, p. 63) destaca os textos de 1943 de José Mariano Filho para enfatizar a persistência do racismo nas análises sobre os mocambos, ainda mais reveladora neste caso por Mariano ser filho de um dos abolicionistas mais estridentes do Recife.

111. Magalhães (1939d). Barreto (1939, p. 33) articula essa opinião através da mocambeira Anastacia, que a certa altura pensa: "Que especie de gente pode se educar numa mocambaria destas no meio de porcos e sirys, sem instrucção nem religião, praticando o catimbó o jogando o bicho? Que especie de gente pode ser esta que se arrasta na lama e somente na lama sabe construir a sua casa?".

112. Magalhães (1939e).
A exemplo de grande parte da retórica do Estado Novo, a linguagem da campanha ao tratar dos mocambos era eclética, refletindo ideias conflitantes sobre como a diferença social deveria ser categorizada e discutida. Em alguns pontos, o tom de Magalhães e seus aliados mais próximos seguia numa linha conservadora e tradicional. Ouviam-se ecos de concepções mais antigas, explicitamente racializadas: num editorial de 1938, a Folha da Manhã lamentava a "Mocambaria Africana" do Recife, com sua "população que quase nada rende em inteligência e economia, no seio da coletividade". Em agosto de 1939, o editor da Folha chamou os mocambos de "puro e lamentável africanismo". ${ }^{108}$ Mocambo, romance de Antônio Barreto, investia contra as religiões afro-brasileiras, retratadas como supersticiosas e exploradoras. ${ }^{109}$ A campanha da Liga rejeitava ainda os elogios dos regionalistas ao mocambo, argumentando que aqueles autores teriam "cerebros evidentemente doentios" e que sua atitude era "snob e literária", de cabo a rabo refutada pela ciência médica. ${ }^{110}$ No entanto, tais referências explícitas à raça e a formas racializadas da cultura eram excepcionais. Os militantes da liga estavam mais propensos a recorrer a conceitos de saúde pública ou a evocar variações da sociologia e da psicologia social que já pavimentavam a via culturalista nas teorias da pobreza. $\bigcirc$ mocambo era, por essa leitura, não apenas "uma habitação antihigiênica", mas também "fator psicológico de depressão social" que impunha as condições para a desgraça: "a vida sem uma ambição, sem um mínimo de prosperidade, não é ascensão, é queda, fracasso, incapacidade de lutar". ${ }^{111}$ Outros textos enfatizavam a anomia da qual supostamente seríam acometidas as populações rurais deslocadas para a cidade. Num artigo em que lamentava a falta de cultivição agrícola em terrenos vazios da municipalidade, Magalhães observou:

O camponez urbaniza-se rapidamente. Deforma-se com a atração das cidades. As horas livres, os dias de folga, os operários dissipam em divertimentos ou recreios que os centros de aglomeração humana oferecem. Não ficam em casa. Não cultivam a sua horta. Não tem a emoção da terra. ${ }^{112}$

Noutros momentos, as categorias relevantes para a questão da desigualdade eram as de atraso, progresso e desenvolvimento econômico, como quando Magalhães reclamou do impacto dos mocambos sobre a imagem internacional do Recife:

O mocambo despede o viajante, porque é a habitação do nativo, a expressão de pauperismo e de desordem económica, que confrange os civilizados. Ninguém acredita que Pernambuco seja essa formidável reserva de trabalho, um parque de atividades agroindustriais, uma economia em reação contra as crises periódicas das secas, um Estado, enfim, onde não ha lugar para os desocupados ou para os que não tem animo de viver. $\bigcirc$ mocambo é o pregão, que esconde o que somos, e que nos degrada, apontando-nos, dentro 
e fora do Brasil, como um povo que não produz, incapaz de vencer a terra e de criar riquezas. Precisamos fazer calar a esse triste pregão, acabando com os mocambos. ${ }^{113}$

Moradias adequadas não apenas passariam uma mensagem quanto à capacidade de desenvolvimento do Recife, como também criariam "pequenos proprietários", "pequenos burgueses" que funcionariam como esteio contra a estagnação e o radicalismo político. ${ }^{114}$ Todos esses argumentos eram expressos na linguagem da engenharia social oriunda daquela classe ascendente de médicos, acadêmicos e especialistas técnicos que acreditavam fervorosamente ser possível a perfectibilidade humana por caminhos específicos e hierarquicamente determinados. Mas a campanha de Agamenon - como grande parte da retórica do Estado Novo que ele moldara como ministro do Trabalho - era também uma reação explícita à ameaça comunista, recorrendo seletivamente a correntes mais radicais e populares. ${ }^{115}$ Acima de tudo, particularmente depois do recenseamento dos mocambos realizado em 1938, Magalhães e a Folha da Manhã abandonaram abruptamente a noção de que os mocambeiros - em vez do próprio mocambo eram a raiz dos problemas sociais do Recife. Ao divulgar os resultados do censo, Magalhães escreveu a respeito dos 164.877 habitantes dos mocambos:

E que população é essa? Será de analfabetos? Será de desocupados? Não. Dois terços dela, ou sejam 62.7 por cento, sabem ler e escrever. São alfabetizados. Quase toda a população dos mocambos trabalha. Tem ocupação. A porcentagem dos desocupados é mínima. Atinge apenas 3.3. Os chefes de família ou são artistas, ou trabalham nas fábricas, no comércio, nos transportes. As mulheres lavam, engomam, quando não são alugadas em outros trabalhos domésticos. As crianças dos mocambos frequentam a escola, numa porcentagem de 62.78.116

Conforme já haviam argumentado os habitantes de São Miguel, os mocambeiros eram trabalhadores e chefes de família, e sua marginalização não decorria nem de um defeito de raça, nem de incapacitação física. Sofriam, em vez disso, com problemas que os comunistas teriam reconhecido: um mercado de trabalho saturado, baixos salários e a exploração brutal dos donos do mocambo. Não eram os mocambeiros que causavam a degradação dos mocambos; ao contrário, eram eles os degradados, e a liga, uma "obra de dignificação da pobreza". ${ }^{117} \bigcirc$ uso de categorias sociais comuns - trabalhadores e chefes de família, de um lado, "marginais", de outro - não significava que os ideólogos comunistas e do Estado Novo tivessem visões de mundo consonantes. Comunistas (e muitos recifenses pobres) consideravam que a culpa pela degradação dos trabalhadores era não apenas dos baixos salários e da exploração, mas também das condições estruturais que tornavam as duas coisas possíveis. Os militantes da liga, por outro lado, culpavam em parte a
113. Magalhães (1939f).

114. Direito de propriedade (1939).

115. Ao promover a liga, Magalhães deixou claras suas intenções anticomunistas: "Lutar contra o mocambo é lutar contra o comunismo, porque todo mocambo é uma célula de descontentamento. Por isso, a luta contra o mocambo precisa do apoio de quantos sentem a necessidade de defender o organismo social das investidas dos inimigos do regimem". A Liga Social... (1939), apud Lima (2006, p. 108).

116. Magalhães (1939j).

117. Essa legenda acompanha foto de Arnóbio Tenório Wanderley na Folha da Manhã, em 26 de junho 1939. 
118. Magalhães (1939k). Cf. também Campello (1939) e Magalhães (1939b).

119. Decretos Municipais 49, 50, 109, e 121 de 1938 e 181 de 1939; Melo (1985, p. 56).

120. Lima (2005, p. 86), e Bezerra (1965, p. 49). Na altura de 1961, depois de 23 anos na ativa, a liga (rebatizada Serviço Social Contra o Mocambo) tinha construído apenas 5.650 casas. Pernambuco (1962, p. 22).

121. Para um relato interessante sobre a tolerância aos mocambos na periferia urbana do Recife nesse mesmo período, cf. Leite (2010).

122. Bezerra (1965, p. 49)

123. Para entender esta memória popular contraditória da campanha, cf. Montenegro (2001). falta de solidariedade cristã. Os "exploradores" eram indivíduos que não compreendiam sua responsabilidade para com o corpo social. Não eram - como "Mostardinha" - o resultado inevitável de um sistema político corrupto que erigira seu poder sobre a exploração. E os baixos salários não decorriam de um descontrole do capitalismo ou de monopólios de proprietários rurais, antes eram, numa inversão lógica perversa, consequência dos próprios mocambos, que ofereciam aos migrantes do campo uma âncora numa cidade à qual não pertenciam. Como escreveu Magalhães: "O mocambo é que gera o pauperismo, o salário baixo, a depressão social. A habitação fácil e miserável atrai os sem trabalho de todas as regiões do nordeste, que se fixem na lama, nos terrenos baldios, nas palhoças e nos casebres de folhas de flandres e pedaços de madeira, em tal número que espanta". ${ }^{118} \mathrm{Uma}$ vez que o próprio mocambo era o inimigo, não havia necessidade de consciência de classe ou de mudança estrutural. Era, sim, necessária uma solução tecnocrática de substituição dos assentamentos por lares higiênicos a um preço apenas suficiente para separar o trigo dos operários do joio dos trabalhadores rurais desnaturados.

A liga não teve sucesso nem por seus próprios critérios: o reconhecimento dos mocambeiros como trabalhadores decentes exigia que, ao menos na aparência, houvesse a substituição das moradias, e nem em sonho a campanha conseguiria dar casa a todos os mocambeiros do Recife. Mesmo que vários decretos e leis fornecessem ao governo municipal ferramentas ainda mais poderosas para combater a proliferação dos mocambos (proibindo a construção e reparação de mocambos, taxando os seus proprietários, incentivando a construção de habitações operárias), as autoridades não dispunham de recursos para construir habitações adequadas para metade da população municipal. ${ }^{119}$ Ao todo, cerca de 12.400 mocambos foram demolidos entre 1939 e 1944, enquanto aproximadamente 5,5 mil pequenas casas eram construídas, a maioria em pequenas "vilas" destinadas a classes específicas de trabalhadores - lavadeiras, cozinheiras etc. ${ }^{120} \bigcirc$ que, ao fim, resultou em deslocamento, em vez de erradicação. Os mocambeiros expulsos das regiões centrais da cidade, juntamente com uma onda de novos migrantes, foram construir seus mocambos em outros lugares: em mangues menos visíveis, nas colinas da Casa Amarela ou num dos distritos ainda rurais do Recife. ${ }^{121}$ Em 1938, os recenseadores contavam 45.581 barracos no Recife; no início dos anos 1960, eles eram cerca de 100 mil. ${ }^{122}$ Na década de 1950, a liga se tornara apenas mais uma repartição pública, e sua investida original era lembrada como uma luta ineficaz e punitiva contra o inevitável impulso da construção informal. ${ }^{123}$ 
Apesar dessas limitações, a mudança de conceitos sobre a diferença social que estruturou a campanha da liga perdurou. Ativistas comunistas, moradores do mocambo e intelectuais regionalistas podiam discordar da liga em sua substância, mas era notável a ausência de discussão acerca dos termos nos quais seriam travadas as batalhas em torno dos assentamentos informais do Recife. Os mocambos podiam ser ora expressão da engenhosidade regional adaptada ao meio, ora versão abastardada e anti-higiênica da sociedade civilizada. Seus moradores podiam ser ora trabalhadores altivos e chefes de família, cujo sofrimento acabaria produzindo uma revolta de classe contra a injustiça estrutural, ora vítimas fragilizadas por desnutrição e doenças, as quais precisavam desesperadamente de assistência governamental. A crise no campo podia ser tanto a raiz do problema dos mocambos, como os próprios mocambos os responsáveis por arrancar os trabalhadores agrícolas do campo. A cultura dos pobres mocambeiros era tratada ora como cooperativa e adaptável, ora como anômica e imoral. No entanto, as categorias explícitas de análise eram pobres e ricos, doentes e saudáveis, rural e urbano, familiar e promíscuo. Na maior parte dos casos, não invocavam abertamente as divisões entre africanos e europeus. A legislação antimocambo, fiel às suas raízes na belle époque, obscureceu suas origens racistas ao enquadrar os debates urbanos em uma lógica de saneamento, urbanismo, corporativismo e desenvolvimento. $\bigcirc$ racismo continuava a operar, assim como a consciência racial e cultural, mas de forma sinuosa e, sobretudo, sem uma linguagem política explícita.

No Brasil, isso se manteria como tendência até a metade do século passado, ao longo de décadas em que a questão da pobreza urbana ganhou centralidade para os movimentos sociais e os debates políticos no país. Pelo menos um admirador da Liga Social Contra o Mocambo, José Tavares de Moura, veio a se tornar também uma liderança numa campanha inovadora para substituir as favelas do Rio de Janeiro por parques proletários, a qual, por sua vez, lançou as bases para cruzadas antifavela nos anos 1940 e 1950.124 Ativistas católicos em todo o país se interessaram pelo trabalho em favelas e mocambos, e por toda parte os comunistas adotaram os tipos de técnica de organização comunitária aplicados com sucesso no Recife no início da década de 1930. Líderes comunitários em várias cidades adotaram estratégias políticas ecléticas e ideologicamente heterogêneas, justificando suas lutas em termos de honra, trabalho e família, o que teria parecido familiar aos moradores da Vila São Miguel. Muitos, ao menos de 
125. Esses debates começaram no final de 1955 e se estenderam até o fim de 1956, quando a chamada "lei da favela" foi aprovada. acordo com registros comunistas, chegaram a expressar a opinião de que, ao articular seus movimentos como lutas pelos direitos urbanos, davam culminação lógica à abolição da escravidão. No Rio, no Recife e em outros lugares, essas lutas muitas vezes resultaram em vitórias ambíguas, na forma de ocupações urbanas informais ou até mesmo - especialmente no Recife - direitos de propriedade precários. $\bigcirc$ afastamento de análises explicitamente racializadas da informalidade urbana, embora não tenha sido total, foi notável. Emblematicamente, em mais de um ano de debates no Congresso sobre o que viria a ser a primeira lei nacional de favelas do Brasil, em 1956, nenhum dos debatedores mencionou o fato de que a maioria dos moradores dessas comunidades era afrodescendente. ${ }^{125}$

Depois da Segunda Guerra Mundial, os mocambos do Recife mudaram de nome e de geografia, e sua militância política se expandiu rapidamente. $\bigcirc$ mocambo folclórico tornou-se a estigmatizada favela ou a politicamente idealizada comunidade. Enquanto a cidade informal seguiu ocupando certas localidades centrais e nobres (Coque, Brasília Teimosa, Entra Apulso), concentrou-se cada vez mais nas periferias, na Casa Amarela, bairro da zona norte, ou nos espaços intersticiais criados por rios e várzeas. E essas concentrações tornaram-se mais e mais politizadas. No final da década de 1940, moradores locais e ativistas comunistas se uniram em "ligas mixtas" que reivindicavam direitos de ocupação e propriedade, além de serviços para os mocambos. Entre meados dos anos 1950 e início dos 1960, novamente em aliança com católicos radicais e comunistas clandestinos, as associações comunitárias da capital pernambucana emergiram como uma força poderosa na Frente do Recife, uma das coalizões de esquerda com mais força a surgir na República brasileira do pós-guerra. $\bigcirc$ golpe militar de 1964 desarticulou a frente, mandando seus líderes para a prisão e o exílio, mas sob liderança católica as associações de bairro perduraram como parte de uma rede de ativismo político de base que permaneceu intacta durante a ditadura. Na altura dos anos 1970, quando a esquerda nacional voltava à tona cautelosamente, o forte movimento das pastorais defendia os direitos territoriais das comunidades em todas as zonas informais do Recife. Elas estiveram no cerne dos experimentos com leis de zoneamento social (Zeis e pré-Zeis) e governança participativa que colocariam o Recife na vanguarda dos movimentos nacionais pelo direito à cidade, posteriormente consagrado na Constituição de 1988 e no Estatuto da Cidade de 2001.

No entanto, ao longo dessas décadas de turbulência e ativismo, a questão da raça permaneceu ambígua, ao mesmo tempo onipresente e invisível. A carga profundamente racial do termo "mocambo" permaneceu, e a grande maioria dos moradores de mocambos e favelas era afrodescendente. Como outros no Brasil, jornais comunistas ou da igreja ocasionalmente destacavam o racismo nos Estados 
Unidos como um flagelo do capitalismo, e sempre comemoravam a Abolição em 13 de maio. Tanto na retórica popular quanto entre esquerdistas, "liberdade" e "escravidão" eram termos politicamente poderosos, frequentemente empregados em relação à necessidade de ampliar direitos de propriedade e tornar a cidadania urbana mais plena. Em todos esses aspectos, os mocambos, especificamente - e a informalidade urbana, em geral - eram entendidos como fenômenos racializados.

Mas até fins do século XX, jornalistas, ativistas e pesquisadores raramente apontavam o racismo como causa da desigualdade urbana, ou mesmo buscavam identificar os mecanismos que perpetuavam a dinâmica racialmente desigual no espaço urbano brasileiro. Pelo contrário, até os ativistas muitas vezes se esforçavam para retratar a cidade informal como um espaço racialmente híbrida: em 1979, por exemplo, um morador do Morro da Conceição observou que, embora o assentamento em suas origens, no início do século XIX, fosse "todo caboclo", mais tarde se tornara um híbrido racialmente igualitário: "Tem essa mistura: aqui tem galego, tem tudo, aqui não tem racismo". ${ }^{26}$ Nas listas de demandas elaboradas pelas várias associações de bairro do Recife, raça e racismo continuaram por muito tempo sem ser temas articulados ou explorados. Enquanto as fotos nos jornais de bairro dos movimentos sociais urbanos da década de 1970 mostram claramente ativistas afrodescendentes, os cartuns que muitas vezes os ilustravam retratavam principalmente traços europeus. A cidade informal do Recife era majoritariamente afrodescendente, mas seus movimentos e suas propostas de políticas permaneciam escrupulosamente silenciosos acerca das questões de raça. Ao enfatizar a igualdade universal em vez da discriminação racial, os advogados e tecnocratas idealistas que construíram o direito à cidade no Recife dos anos 1980 em diante simplesmente seguiam essa mesma diretriz.

Sempre foi difícil, nas discussões sobre as concepções brasileiras de diferença social no século XX, entender o significado do silêncio sobre da questão racial. A mesma linguagem universal que abriu o sonho de cidadania e liberdade aos egressos do cativeiro se convertiu em um obstáculo árduo quando os afro-brasileiros chegaram a desafiar o preconceito racial que impedia que os sonhos de igualdade cidadã fossem realizados. Conforme atesta o caso dos mocambos do Recife, o silêncio racial podia ser algo imposto, evocado para abafar a consciência de raça ou usado para disfarçar formas de racismo socialmente inaceitáveis. No entanto, esse silêncio podia significar ainda muitas outras coisas: uma opção política, uma escolha tática, a consequência não prevista de uma ampla gama de estratégias sociopolíticas que procuravam atacar o denso nó de desigualdades no país. É fácil entender que, num contexto de profundo racismo, a esperança de um igualitarismo que desconsidere diferenças de raça exerça grande atração. Isso é especialmente verdadeiro no que 
tange aos movimentos sociais urbanos, os quais emergiram de alguns dos espaços mais racialmente estigmatizados do Brasil e desempenharam um papel fundamental na garantia dos direitos de ocupação urbana e de mobilidade social aos afrobrasileiros ao longo de todo o século XX.

No entanto, o tempo em que vivemos revelou os limites dessa atração. Num momento em que o movimento pelo direito à cidade se consolida como lei, os habitantes majoritariamente negros das cidades informais do Brasil seguem impossibilitados de reivindicar direitos iguais, ou mesmo, por vezes, quaisquer direitos. $\bigcirc$ problema da igualdade não está nas leis, mas no acesso a elas, e os processos que regem esse acesso nas cidades brasileiras claramente produzem resultados com viés racial. Para entender como e por que isso acontece, é preciso romper e desmembrar o muro de silêncio racial que foi tão cuidadosamente construído em volta da questão urbana no Brasil ao longo do século 20. 


\section{REFERÊNCIAS}

FONTES MANUSCRITAS

APEJE, Fundo SSP, no. 420, Prontuário 260, arquivo \#1 [s.d.].

ARQUIVO Público Estadual Jordão Emerenciano (APEJE), Fundo SSP, no. 420, Prontuário 260, arquivo \#1, petição [s.d.].

COMUNICADO da Secretaria de Segurança Pública, Delegacia de Vigilância Geral e Costumes, 31 de maio de 1941, assinado por Pedro A. Neves, Guarda Civil de 1a Classe.

LIGA Mixta dos Proprietarios da Vila São Miguel, "convites” sem data, [1935?] (APEJE), Fundo SSP, no. 420, Prontuário 260, arquivo \#1.

FONTES IMPRESSAS

A ESTATISTICA na solução dos problemas sociais, Folha da Manhã, 5 nov. 1938.

A LIGA Social Contra o Mocambo. Folha da Manhã, Recife, 9 set. 1939.

AS ELEICOES municipaes, Folha do Povo, 4 set. 1935.

BRAGA, Rubem. O Caranguejo e o Pobre. Folha do Povo, Recife, 22 ago. 1935.

CAMPELlO, José. Os aspectos sociaes e económicos do mocambo. Folba da Manhã, Recife, 30 jul. -1 ago. 1939.

DIREITO de propriedade. Folha da Manhã, Recife, 28 jul. 1939.

EXPLORAÇÃO brutal contra os moradores de mocambos. Folha do Povo, Recife, 22 ago. 1935

EXPOLIADO por Mostardinha: perdeu o mocambo que lhe custara muito trabalho e 300 mil reis. Folba do Povo, Recife, 27 jul. 1935. 
FILANTROPIA de Mostardinha. Folha do Povo, Recife, 30 ago. 1935.

HISTÓRIA do Movimento de Bairro. Folha dos Bairros, Recife, abr. 1987.

MAGAlHÃES, Agamenon. Ainda o Problema dos Mocambos. Folba da Manhã, Recife, 14 set. 1939a.

MAGALHÃES, Agamenon. Concentração urbana. Folha da Manhã, Recife, 18 jul. 1939b.

MAGAlHÃeS, Agamenon. O ciclo do carangueijo. Folha da Manhã, Recife, 6 jul. 1939c.

MAGAlHãeS, Agamenon. O gosto pela habitação. Folha da Manhã, Recife, 4 jul. 1939d.

MAGALHÃES, Agamenon. O pequeno agricultor. Folha da Manhã, Recife, 1 jul. 1939e.

MAGAlHÃES, Agamenon. Triste pregão. Folha da Manhã, Recife, 15 jul. 1939f.

MAGALHÃES, Agamenon. Na cruzada contra o mocambo. Folha da Manhã, Recife, 11 Julho 1939g.

MAGAlHãeS, Agamenon. Males do mocambo. Folha da Manhã, Recife, 12 jul. 1939h.

MAGAlHÃES, Agamenon. Iniciativa particular. Folha da Manhã, Recife, s/d (1939i).

MAGAlHÃES, Agamenon. Problema humano. Folba da Manhã, Recife, s/d (jun. 1939j).

MAGAlHÃES, Agamenon. Controversia. Folha da Manhã, Recife, 30 jul. 1939k.

MORTALIDADE infantil e mocambos, Folha da Manhã, 29 mar. 1939.

MOSTARDINHA - senhor feudal de um povoado de lama. Folha do Povo, Recife, 24 jul. 1935.

OBRA de dignificação da pobreza, Folha da Manhã, 26 jun. 1939.

PAI Velho conta a história do Morro da Conceição, Jornal dos Bairros, ano I, v. 6, jan. 1979.

REUNE-SE amanhã, a liga social contra o mocambo. Folha da Manhã, Recife, 23 jul. 1939. 
REVOLTANTE atitude da prefeitura. Folha do Povo, Recife, 19 ago. 1935.

TAVARES, Claudio. Palavras a um negro. Folha do Povo, Recife, 17 set. 1935.

TRABALHADOR, Ocupa Teu Posto! O manifesto dirigido ao eleitorado pela querida e popular legenda. Folha do Povo, Recife, 4 out. 1935.

VIVENDO na lama e comendo carangueijo: 100,000 párias devastados pela fome a padecer misérias nos 20,000 mocambos do Recife. Folha do Povo, Recife, 23 out. 1935

LIVROS, ARTIGOS E TESES

ALBERTI, Verena; PEREIRA, Amilcar Araujo. Histórias do movimento Negro no Brasil, Rio de Janeiro: CPDOC, 2007.

ALBERTO, Paulina. Terms of Inclusion. Chapel Hill: UNC Press, 2011.

ALBUQUERQUE, Wlamyra. O jogo da dissimulação. São Paulo: Companhia das Letras, 2009.

ASSIES, Willem. To Get Out of the Mud. Amsterdã: CEDLA, 1991.

ASSIES, Willem. Reconstructing the Meaning of Urban Land in Brazil: The Case of Recife (Pernambuco). In: JONES, Gareth; WARD, Peter (orgs.). Methodology for Land and Housing Market Analysis. Londres: UCL Press, 1994. p. 102-117.

BARRETO, Antonio. Mocambo. Recife: Livraria Universal, 1939.

BENCHIMOL, Jaime. Pereira Passos: Um Haussmann tropical. Rio de Janeiro: Biblioteca Carioca, 1990.

BEZERRA, Daniel Uchoa Cavalcanti. Alagados, mocambos e mocambeiros. Recife: Instituto Joaquim Nabuco: Imprensa Universitária, 1965.

BLAKE, Chip. The Medicalization of Nordestinos. The Americas, v. 60, n. 2, p. 217-48, 2003.

BORGES, Dain. "Puffy, Slothful and Intert": Degeneration in Brazilian Social Thought, 18801940. Journal of Latin American Studies, v. 25, n. 2, p. 235-57, 1993. 
BRAGA, Rubem. O conde e o passarinho. Rio de Janeiro: Olympio, 1936.

BRUM, Mário. Cidade Alta. Rio de Janeiro: Ponteio, 2012.

CASTRO, Josué de. A cidade do Recife: ensaio de geografia urbana. Rio de Janeiro: Livraria-Editôra da Casa do Estudante do Brasil, 1954.

CASTRO, Josué de. Documentário do Nordeste. Rio de Janeiro: J. Olympio, 1957.

CASTRO, Josué de. Geografia da fome. Rio de Janeiro: O Cruzeiro, 1946.

CASTRO, Josué de. Homens e caranguejos. São Paulo: Brasiliense, 1967.

CAVALCANTI, Carlos Bezerra. O Recife e seus bairros. Recife: Câmara Municipal do Recife, 1998.

CÉZAR, Maria do Céu do E. S. As organizações populares do Recife. Cadernos de estudos sociais, v. 1, n. 2, p. 161-182, 1985.

CÉZAR, Maria do Céu do E. S.; COSTA, Lia Parente. Lutas populares por habitação: mocambos, cortiços e vilas operárias em Recife e São Paulo. Recife: Fase, 1992.

CHALHOUB, Sidney. Cidade febril: cortiços e epidemias na corte imperial. São Paulo: Companhia das Letras, 1996.

CHAlHOUB, Sidney. The Politics of Silence: Race and Citizenship in 19th Century Brazil. Slavery and Abolition, v. 27, n. 1, p. 73-87, 2006.

CHALHOUB, Sidney. Visões da liberdade. Uma história das últimas décadas da escravidão na corte. São Paulo: Companhia das Letras, 1990.

CICALO, André. "Those Stones Speak": Black-Activist Engagement with Slavery Archaeology in Rio de Janeiro. Latin American and Caribbean Ethnic Studies, v. 10, n. 3, p. 251-270, 2015.

COELHO, Edmundo Campos. As profissões imperiais: medicina, engenharia e advocacia no Rio de Janeiro, 1822-1930. Rio de Janeiro: Record, 1999.

COLLINS, John. Revolt of the Saints: Memory and Redemption in the Twilight of Brazilian Racial Democracy. Durham: Duke University Press, 2015. 
DRAKE, St. Clair. Black Metropolis: A Study of Negro Life in a Northern City. Nova York: Harcourt, 1945.

FERNANDES, Edésio. Constructing the "Right to the City" in Brazil. Social Legal Studies, v. 16, p. 201-219, 2007.

FERNANDES, Edésio. The Challenges of Reforming the Urban Legal Framework: A Critical Assessment of Brazil's City Statute Ten Years Later. The World Bank Law Review, v. 5, p. 279-291, 2013.

FERNANDES, Edésio. Regularising Informal Settlements in Brazil: Legalisation, Security of Tenure and City Management. ESF/N-Aerus Annual Workshop, p. 23-26, maio 2001.

FERNANDES, Florestan. A integração do negro na sociedade de classes. São Paulo: Dominus, 1965.

FILGUEIRA FILHO, Valdemar de Oliveira. Mocambo, comédia social em 3 atos. Recife: Imprensa Oficial, 1940.

FISCHER, Brodwyn. A Century in the Present Tense: Crisis, Politics and the Intellectual History of Brazil's Informal Cities. In: FISCHER, Brodwyn; MCCANN, Bryan ; AUYERO, Javier. Cities from Scratch: Poverty and Informality in Urban Latin America. Durham: Duke University Press, 2014. p. 9-67.

FISCHER, Brodwyn. A Poverty of Rights: Citizenship and Inequality in Twentieth-Century Rio de Janeiro. Stanford, CA, EUA: Stanford University Press, 2008

FISCHER, Brodwyn. Partindo a cidade maravilhosa. In: GOMES, Flávio dos Santos; CUNHA, Olívia Maria Gomes da. Quase cidadão: histórias e antropologias da pós-emancipação no Brasil. Rio de Janeiro: FGV, p. 419-450, 2007.

FISCHER, Brodwyn. "Quase pretos de tão pobres?" Race, class and Criminal Justice in Rio de Janeiro. Latin American Research Review, v. 39, n. 4, p. 31-59, 2004.

FISCHER, Brodwyn; GRINBERG, Keila; MATTOS, Hebe. Direito, silêncio e racialização das desigualdades na história afro-brasileira. In: DE LA FUENTE, Alejandro; ANDREWS, Reid. Estudos Afro-Latino-Americanos: Uma Introdução. Buenos Aires: CLACSO, p. 163-215, 2018.

FREITAS, Otávio. Um século de medicina e higiene no Nordeste. FREYRE, Gilberto; MOTA, Mauro. Livro do Nordeste. Recife: Secretaria da Justiça: Arquivo Público Estadual, p. 29-35, 1979. 
FREYRE, Gilberto. Mucambos do Nordeste. Rio de Janeiro: Ministério da Educação e Saúde, 1937.

FREYRE, Gilberto. Manifesto Regionalista. 4. ed. Recife: Instituto Joaquim Nabuco de Pesquisas Sociais, 1967.

FREYRE, Gilberto. Sobrados e Mucambos. São Paulo: Global, 2004.

FREYRE, Gilberto; JARDIM, Luís. Guia prático, histórico e sentimental da cidade do Recife. Rio de Janeiro: José Olympio, 1961.

FREYRE, Gilberto; MOTA, Mauro. Livro do Nordeste. Recife: Secretaria da Justiça: Arquivo Público Estadual, 1979.

GARCIA, Antônia dos Santos. Desigualdades raciais e segregação urbana em antigas capitais. Rio de Janeiro: Garamond, 2009.

GOMINHO, Zélia de Oliveira. Veneza americana $x$ mucambópolis: o Estado Novo na cidade do Recife (décadas de 30 e 40). Recife: Cepe, 1998.

GONDIM, Umberto. A habitação operária. Boletim de Engenharia, v. 1, n. 12, 1924.

GONÇALVES, Rafael Soares. Favelas do Rio de Janeiro. Rio de Janeiro: PUC, 2016.

GUEDES, Paulo. A drenagem superficial do Recife como fator para a salubridade. Boletim de Engenharia, v. 3, n. 2, p. 61-73, 1928.

GUIMARÃES, Valéria Lima. O PCB cai no samba: os comunistas e a cultura popular, 1945-1950. Rio de Janeiro: Arquivo Público do Estado do Rio de Janeiro, 2009.

GUSMÃO, Hugo Barbosa de. Mapa Racial: Cidade do Rio de Janeiro. In: Desigualdades espaciais. 4 nov. 2015. Disponível em: <https://bit.ly/37OnNtD>. Acesso em: 23 fev. 2020.

HOCHMAN, Gilberto. A era do saneamento: as bases da política de saúde pública no Brasil. São Paulo: Hucitec: ANPOCS, 1998.

HOLSTON, James. Insurgent Citizenship. Princeton: Princeton University Press, 2008. 
LEITE, Ricardo. Recife dos morros e córregos. [Trabalho apresentado e não publicado]. Encontro Nacional de História Oral (X). Recife, Pernambuco, 2010.

LIMA, Antonio Vidal de; CRUZ, Arnaldo Rodrigues da; SILVA, João Lopes da; VENTURA, Iêda; MONTENEGRO, Antônio Torres. Casa Amarela: memórias, lutas, sonhos. Recife: Departamento de Memória de Casa Amarela/FEACA, 1988.

LIMA, Ivaldo Marciano de França. Entre Pernambuco e a África. História dos Maracatus-Nação do Recife e a Espetacularização da Cultura Popular (1960-2000). 2010. Tese (Doutorado em História) - Universidade Federal Fluminense, Niterói, 2010.

LIMA, Ivaldo Marciano de França; GUILLÉN, Isabel Cristina Martins. Cultura Afro-Descendente no Recife: Maracatus, Valentes e Catimbós. Recife: Bagaço, 2007.

LIMA, Jacqueline de Cassia Pinheiro. A pobreza como um problema social: as ações de Victor Tavares de Moura e Agamenon Magalhães nas favelas do Rio e nos mocambos do Recife durante o Estado Novo. 2006. Dissertação (Mestrado) - Instituto Universitário de Pesquisas do Rio de Janeiro, Rio de Janeiro, 2006.

LIMA, Nísia Trindade; HOCHMAN, Gilberto. Condenado pela raça, absolvido pela medicina: o Brasil descoberto pelo movimento sanitarista da Primeira República. In: MAIO, Marcos Chor; SANTOS, Ricardo Ventura (Orgs.). Raça, ciência e sociedade. Rio de Janeiro: Fiocruz: CCBB, p. 23-40, 1996.

LIMA, Rosa Maria Cortês de. A cidade autoconstruída. 2005. Tese (Doutorado) - Instituto de Pesquisa e Planejamento Urbano e Regional da Universidade Federal do Rio de Janeiro, Rio de Janeiro, 2005.

LIRA, José Tavares Correia de. A construção discursiva da casa popular no Recife (década de 30). Análise Social, v. 29, n. 3, p. 733-53, 1994.

LIRA, José Tavares Correia de. Hidden Meanings: The Mocambo in Recife. Social Science Information, v. 38, n. 2, p. 297-327, 1999a.

LIRA, José Tavares Correia de. O urbanismo e o seu outro: raça, cultura e cidade no Brasil (1920-1945). Revista Brasileira de Estudos Urbanos e Regionais, v. 1, n. 1, p. 47-78, 1999b.

LOPES, Gustavo Acioli. A cruzada modernizante e os infiéis no Recife, 1922-1926: higienismo, vadiagem e repressão policial. 2003. Dissertação (Mestrado em História) - Universidade Federal de Pernambuco, Recife, 2003. 
MAIO, Marcos Chor; SANTOS, Ricardo Ventura (Orgs.). Raça, ciência e sociedade. Rio de Janeiro: Fiocruz: CCBB, 1996.

MATTOS, Hebe. Das cores do silêncio. Rio de Janeiro: Arquivo Nacional, 1993.

MCCANN, Bryan. Hard Times in the Marvelous City. Durham: Duke University Press, 2014.

MEADE, Teresa A. “Civilizing” Rio: Reform and Resistance in a Brazilian City, 1889-1930. State College, PA, EUA: Pennsylvania State University Press, 1996.

MEDEIROS, Amaury. Saúde e Assistência 1923-1926: doutrinas, experiências e realizações. Recife: [s. n.], 1926.

MEDINA, Luciano Lacerda. A Reinvenção da Quadra. Tese (Doutorado) - Programa de Pósgraduação em Desenvolvimento Urbano. Universidade Federal de Pernambuco, Recife, 2018.

MELO, Marcus André B. C. de. A cidade dos mocambos: estado, habitação e luta de classes no Recife (1920/1960). Espaço e Debates, v. 14, p. 44-66, 1985.

MELO, Mário Lacerda de. Pernambuco: traços de sua geografia humana. Recife: Jornal do Commercio, 1940.

MELO, Mario Lacerda de; GONÇALVES, Antônio Carolino; MACIEL, Paulo; CRUZ, Levy. As migrações para o Recife. Recife: Instituto Joaquim Nabuco de Pesquisas Sociais, 1961. 4 vols.

MIRANDA, Lívia; MORAES, Demóstenes. O plano de regularização das zonas especiais de interesse social do Recife. In: CARDOSO, Arduato Lucio. Habitação social nas metrópoles brasileiras. Porto Alegre: Habitare, 2007. p. 416-435

MONTENEGRO, Antônio Torres. História oral e memória: a cultura popular revisitada. São Paulo: Contexto, 2001.

MORAES, Demóstenes. Revisitando as ZEIS e o PREZEIS no Recife: entre o "reformismo" e o direito à cidade. XVII ENANPUR. Anais. ST. 5.10.03. São Paulo, 2017. Disponível em: <https:// bit.ly/2VeAw6d>. Acesso em: 23 fev. 2020.

NASCIMENTO, Luiz do. História da imprensa de Pernambuco, 1821-1954. Vol. III. Recife: Arquivo Público: Imprensa Oficial, 1962. 
NEEDELL, Jeffrey. The Revolta Contra Vacina of 1904. Hispanic American Historical Review, v. 67 , n. 2, p. 233-69, 1987.

OLIVEIRA, Reinaldo José de. Segregação urbana e racial na cidade de São Paulo: as periferias de Brasilândia, Cidade Tiradentes e Jardim Ângela. 2008. Tese (Doutorado) - Pontifícia Universidade Católica de São Paulo, São Paulo, 2008.

OLIVEIRA, Reinaldo José de; OLIVEIRA, Regina Marques de Souza. Origens da segregação racial no Brasil. Amérique Latine Histoire et Mémoire/Les Cahiers ALHIM [internet], 29, 2015, 18 jun. 2015. Disponível em : <https://bit.ly/2TcdmLn>. Acesso em: 23 fev. 2020.

ORLANDO, Artur. Porto e cidade do Recife. Recife: Jornal do Recife, 1908.

PASCHEL, Tianna. Becoming Black Political Subjects: Movements and Ethno-Racial Rights in Colombia and Brazil. Princeton: Princeton University Press, 2018.

PANDOLFI, Dulce Chaves. Pernambuco de Agamenon Magalhães: consolidação e crise de uma elite política. Recife: Fundação Joaquim Nabuco: Massangana, 1984.

PERNAMBUCO. Programa de habitação popular. Pernambuco: Imprensa Oficial, 1962.

PERNAMBUCO. Comissão Censitária dos Mocambos. Observações estatísticas sobre os mucambos do Recife. Recife: Imprensa Oficial, 1939.

PERNAMBUCO. Departamento de Saúde e Assistência, Inspetoria de Estatística Propaganda e Educação Sanitária. Recenseamento do Recife, 1923. Recife: Secção Técnica da Repartição de Publicações Oficiais, 1924.

PERRY, Keisha-Khan. Black Women against the Land Grab. St. Paul, MN, EUA: University of Minnesota Press, 2013.

POETS, Desirée. "This is not a Favela”: Rio de Janeiro's Urban Quilombo Sacopã and the Limits of Multiculturalism. Bulletin of Latin American Research, v. 36, n. 4, p. 409-423, out. 2017.

RECIFE; CORREA, Eudoro; FERRAZ, Alfredo Vaz de Oliveira. Recenseamento realizado em 12 de Outubro de 1913. Recife: Escolas Profissionaes do Collegio Salesiano, 1915.

RÊGO, José Lins do. O moleque Ricardo. Rio de Janeiro: José Olympio, 1940. 
RIBEIRO, Antônio Carlos Chagas. Mocambos. Recife: Mozart, 1935.

RIOS NETO, Eduardo; RIANI, Juliana de Lucena Ruas. Desigualdades raciais nas condições habitacionais da população urbana. Belo Horizonte: Fundação João Pinheiro, 2007.

ROLNIK, Raquel. A cidade e a lei. São Paulo: Studio Nobel, 1997.

ROLNIK, Raquel. Democracy on the Edge: Limits and Possibilities in the Implementation of an Urban Reform Agenda in Brazil. International Journal of Urban and Regional Research, v. 35, n. 2, p. 239-55, 2011.

ROTHSTEIN, Richard. The Color of Law: A Forgotten History of How our Government Segregated America. New York: Liveright, 2017.

SAMPAIO, Alde. A Casa Tropical. Boletim de Engenharia, v. 3, n. 2, p. 31-43, 1927.

SANTOS, Renato Emerson dos. Questões urbanas e racismo. Petrópolis: DP et Alii Editora, 2012.

SCHWARCZ, Lilia Moritz. O Espetáculo das raças: cientistas, instituições e questão racial no Brasil, 1870-1930. São Paulo: Companhia das Letras, 1993.

SEVCENKO, Nicolau. A revolta da vacina: mentes insanas em corpos rebeldes. São Paulo: Scipione, 2001.

SILVA, Geraldo Gomes da. Aluízio Bezerra Coutinho: um cientista a serviço da arquitetura racionalista. Risco Revista de Pesquisa em Arquitetura e Urbanismo [internet], n. 2, p. 79-82, 1 jul. 2005.

SKIDMORE, Thomas. Black into White; Race and Nationality in Brazilian Thought. Nova York: Oxford University Press, 1974.

SOUSA, Alberto. Do mocambo à favela: Recife, 1920-1990. João Pessoa: Editora Universitária, 2003.

SOUZA, Flavio A.M. de. The Future of Informal Settlements. Geoforum, v. 32, p. 483-492, 2001.

STEPAN, Nancy. The Hour of Eugenics: Race, Gender, and Nation in Latin America. Ithaca, NY: Cornell University Press, 1991. 
TELLES, Edward. Race in Another America: The Significance of Skin Color in Brazil. Princeton: Princeton University Press, 2004.

TEVES, Matias. Entre os mocambos de Recife: Frei Casimiro Brochtrup, O.F.M., o missionário dos pobres. Salvador: Mensageiro da Fé, 1948.

TOLLENARE, Louis-François. Notas dominicais tomadas durante uma residência em Portugal e no Brasil nos annos de 1816, 1817, e 1818 (parte relativa a Pernambuco). [Traduzido do manuscrito francês inédito por Alfredo de Carvalho]. Recife: Jornal do Recife, 1905.

VALLADARES, Licia do Prado. A invenção da favela: do mito de origem a favela.com. Rio de Janeiro: FGV, 2005.

FONTES AUDIOVISUAIS

MEMÓRIA do esquecimento. [Documentário]. Direção e produção: André Cicalò. [s. 1.], Media Centre, Universidade de Manchester; Granada Cente for Visual Antropology, 2011.

Tradução: Christian Schwartz

Artigo apresentado em 31/03/2019. Aprovado em 11/12/2019. (cc) BY 